\title{
Antiepileptogenic and Neuroprotective Effects of Pergularia daemia on Pilocarpine Model of Epilepsy
}

\begin{abstract}
Antoine K. Kandeda ${ }^{1,2}$, Germain S. Taiwe ${ }^{3}$, Fleur C. O. Moto ${ }^{4}$, Gwladys T. Ngoupaye ${ }^{5}$, Gisele C. N. Nkantchoua ${ }^{2}$, Jacqueline S. K. Njapdounke ${ }^{2}$, Jean P. O. Omam ${ }^{2,4}$, Simon Pale ${ }^{2,3}$, Nadege Kouemou ${ }^{2,3}$ and Elisabeth $\mathrm{Ngo} \mathrm{Bum}^{2,6 *}$

'Department of Animal Biology and Physiology, Faculty of Science, University of Yaoundé l, Yaoundé, Cameroon, ${ }^{2}$ Department of Biological Sciences, Faculty of Science, University of Ngaoundere, Ngaoundere, Cameroon, ${ }^{3}$ Department of Zoology and Animal Physiology, Faculty of Science, University of Buea, Buea, Cameroon, ${ }^{4}$ Department of Biological Sciences, Higher Teachers' Training College, University of Yaounde I, Yaounde, Cameroon, ${ }^{5}$ Department of Animal Biology, Faculty of Science, University of Dschang, Dschang, Cameroon, ${ }^{6}$ Institute of Mining and Petroleum Industries, University of Maroua, Kaele, Cameroon
\end{abstract}

OPEN ACCESS

Edited by:

Nouria Lakhdar-Ghazal, Mohammed V University at Agdal, Morocco

Reviewed by: Marina Bentivoglio,

University of Verona, Italy

Astrid Nehlig,

Institut National de la Santé et de la

Recherche Médicale (INSERM),

France

*Correspondence: Elisabeth Ngo Bum eli_bum@yahoo.fr

Specialty section: This article was submitted to

Ethnopharmacology,

a section of the journal

Frontiers in Pharmacology

Received: 31 March 2017

Accepted: 19 June 2017

Published: 30 June 2017

Citation:

Kandeda AK, Taiwe GS, Moto FCO,

Ngoupaye GT, Nkantchoua GCN,

Njapdounke JSK, Omam JPO,

Pale S, Kouemou N and Ngo Bum E

(2017) Antiepileptogenic

and Neuroprotective Effects

of Pergularia daemia on Pilocarpine

Model of Epilepsy.

Front. Pharmacol. 8:440.

doi: 10.3389/fphar.2017.00440
In this study, we investigated antiepileptogenic and neuroprotective effects of the aqueous extract of Pergularia daemia roots (PDR) using in vivo and in vitro experimental models. In in vivo studies, status epilepticus caused by pilocarpine injection triggers epileptogenesis which evolves during about 1-2 weeks. After 2 h of status epilepticus, mice were treated during the epileptogenesis period for 7 days with sodium valproate and vitamin C (standards which demonstrated to alter epileptogenesis), or Pergularia daemia. The animals were then, 1 week after status epilepticus, challenged with acute pentylenetetrazole (PTZ) administration to test behaviorally the susceptibility to a convulsant agent of animals treated or not with the plan extract. Memory was assessed after PTZ administration in the elevated plus maze and T-maze paradigms at 24 and $48 \mathrm{~h}$. Antioxidant and acetylcholinesterase activities were determined in the hippocampus after sacrifice, in vitro studies were conducted using embryonic rat primary cortical cultures exposed to L-glutamate. Cell survival rate was measured and apoptotic and necrotic cell death determined. The results showed that chronic oral administration of PDR significantly and dose-dependently increased the latency to myoclonic jerks, clonic seizures and generalized tonic-clonic seizures, and the seizure score. In addition, PDR at all doses (from 4.9 to $49 \mathrm{mg} / \mathrm{kg}$ ) significantly decreased the initial and retention transfer latencies in the elevated plus maze. Interestingly PDR at the same doses significantly increased the time spent and the number of entries in T-maze novel arm. PDR significantly increased the activities of acetylcholinesterase and antioxidant enzymes superoxide dismutase, catalase, and total glutathione and proteins, and decreased malondialdehyde level. Furthermore, PDR increased viability rate of primary cortical neurons after L-glutamate-induced excitotoxicity, in a dose dependent manner. Altogether these results suggest that PDR has antiepileptogenic and neuroprotective effects, which could be mediated by antioxidant and antiapoptotic activities.

Keywords: antiepileptogenic, antioxidant, neuroprotective, Pergularia daemia, pilocarpine, status epilepticus 


\section{INTRODUCTION}

Temporal lobe epilepsy (TLE) is a neurological disease that may originate from early precipitating events such as febrile seizures, head trauma, status epilepticus (SE), and infections (Loscher and Brandt, 2010; Kan et al., 2012). The activation of glutamate ionotropic receptors triggers neuronal injury or death predominantly mediated by excessive influx of calcium into neurons through ion channels (Emerit et al., 2004). Therefore, the latter events would be followed by a progressive latent phase of epileptogenesis, leading eventually to spontaneous recurrent seizures and which could also cause cognitive impairment (Marcangelo and Ovsiew, 2007). It was proposed that during epileptogenesis reactive oxygen species overproduction may cause an overwhelming intrinsic antioxidant scavenging capacity, resulting in the development of oxidative stress (Azam et al., 2010), as well as associated tissue injury and apoptotic processes (Todorova et al., 2004; Noor et al., 2015). Despite the high number of antiepileptic drugs currently available, pharmacological agents able to prevent epileptogenesis are lacking. In addition, a high percentage of TLE patients (40\%) do not respond to conventional antiepileptic drugs (Kwan and Brodie, 2003; Loscher and Brandt, 2010). Thus, new antiepileptic drugs, possibly with antiepileptogenic properties, are needed. Medicinal plants represent a potential source of such compounds.

According to World Health Organization, about threequarters of the world population rely upon traditional remedies, mainly medicinal plants (Gilani and Rahman, 2005; Rahmati et al., 2013). Among these, the African and Asian tropical/subtropical plant Pergularia daemia (Forsk.) Chiov. (Asclepiadaceae) (P. daemia) is used in African and Indian traditional medicine to treat leprosy, poisoning, asthma, anemia, seizures, and mental disorders (Mittal et al., 1962; Karthishwaran and Mirunalini, 2010; Sravani et al., 2012; Sridevi et al., 2014). In Northern Cameroon and in Benin, traditional healers use decoctions of $P$. daemia roots to treat malaria, febrile seizures, epilepsy, mental, and inflammatory disorders (Arbonnier, 2002).

Phytochemically, alkaloids, flavonoids, saponins, triterpenes, tannins and steroidal compounds have been searched in P. daemia roots (Bhaskar and Balakrishnan, 2009; Sridevi et al., 2014). Phytochemicals like glucosides and cardenolides in seed, coroglaucigenin, corotoxigenin, uscharidin, and uzarigenin in stem have been identified (Bhaskar and Balakrishnan, 2009; Sridevi et al., 2014). Roots of $P$. daemia were reported to contain $\beta$-sitosterol, lupeol, lupeol acetate, and $\beta$-amyrin and its acetate (Bhaskar and Balakrishnan, 2009; Sridevi et al., 2014). Organic esters, fatty acids, and phenolic compounds were identified by analysis of the ethanolic extract of the plant (Bhaskar and Balakrishnan, 2009; Sridevi et al., 2014). Various pharmacological properties, including hepatoprotective, antidiabetic, anti-inflammatory, antioxidant, antipyretic, analgesic, and sedative activities have been reported in whole plant extracts (Wahi et al., 2002; Suresh and Mishra, 2008). Aqueous, ethanolic and petroleum ether extracts of $P$. daemia leaves exhibited significant analgesic, antioxidant, antipyretic activities, and antibacterial properties (Suresh and Mishra, 2008). Moreover, active compounds like kaempferol extracted from the roots demonstrated antiepileptic activities (Lokesh, 2009; Sravani et al., 2012).

In the present study, to assess antiepileptogenic effect of P. daemia extract, the pilocarpine-induced SE model was used. In this paradigm, $\mathrm{SE}$ was induced in mice by intraperitoneal pilocarpine injection. Animals that developed SE for $2 \mathrm{~h}$ were selected and received $P$. daemia extract for 7 days (i.e., during the epileptogenesis period). The effects of $P$. daemia were compared to those of sodium valproate (a widely used antiepileptic drug) and vitamin $C$ (an exogenous antioxidant known to inhibit oxidative stress in the brain). These drugs are known to modify epileptogenesis process (Brandt et al., 2003; Xavier et al., 2007; Loscher and Brandt, 2010). During the epileptogenesis period, animals were challenged with pentylenetetrazole (PTZ) in order to assess the susceptibility of animals to seizures and behavioral alterations (Ilhan et al., 2005; Blanco et al., 2009). Effects of the extract on excitotoxicity induced by L-glutamate were assessed on primary cortical neurons in culture. To date, no published study assessed antiepileptogenic and neuroprotective properties of $P$. daemia extract. Therefore, the aim of this study was to assess the putative antiepileptogenic and neuroprotective effects of the aqueous extract of $P$. daemia roots prepared mimicking the traditional healer decoction.

\section{MATERIALS AND METHODS}

\section{Drugs and Chemicals In Vivo Studies}

Vitamin C, PTZ, scopolamine methyl nitrate, diethyl ether, pilocarpine hydrochloride, sodium valproate, Biuret reagent, acetylcholine iodide, 5'5-dithiobis-(2-nitrobenzoic acid) (DNTB), adrenaline, acetic acid, dichromate, hydrogen peroxide $\left(\mathrm{H}_{2} \mathrm{O}_{2}\right)$, Tris-Hcl, trichloroacetic acid, thiobarbituric acid, sodium phosphate buffer, Griess reagent were purchased from Sigma Chemical Co., St. Louis (United States), while diazepam was purchased from Roche, Neuilly sur-Seine, France. The minimal dose of chemoconvulsant at which $99 \%$ of the animals showed a convulsion was determined based on the doses used by other researchers and by a dose-percentage effect curve (Miller and Tainter, 1944; Ahmadiani et al., 2003). Vitamin C and sodium valproate were dissolved in distilled water. All solutions were prepared freshly in the day of the experiment and were administered intraperitoneally at a volume of $10 \mathrm{ml} / \mathrm{kg}$, except for distilled water and aqueous extract of $P$. daemia administered per os at the same volume.

\section{In Vitro Studies}

$\beta$-D-arabinofuranoside hydrochloride, Hoechst 33342, propidium iodide, 3-(4,5-dimethylthiazol-2-yl)-2,5diphenyltetrazolium bromide (MTT), oxamate, dimethyl sulfoxide (DMSO), sodium bicarbonate, phosphate buffer saline (PBS), nicotinamide dinucleotide adenine (NAD), diaphorase, L-glutamic acid monosodium salt hydrate, polyL-lysine, Dulbecco's modified Eagle's medium (DMEM), $\beta$-mercaptoethanol, lactate, L-glutamine were purchased from Sigma-Aldrich (St. Louis, MO, United States). Fetal 
bovine serum (FBS) and bovine serum albumin (BSA) were purchased from Gibo/Invitrogen (Carlsbad, CA, United States). Penicillin and streptomycin were purchased from Sanofi-Aventis (Guildford, United Kingdom).

\section{Plant}

\section{Collection and Identification}

Fresh roots of $P$. daemia were harvested during the month of June 2012 in Mayo-Tsanaga division (Far-North Region, Cameroon). A voucher specimen has been deposited at the Yaoundé national herbarium on the number 7797/SRF/Cam.

\section{Preparation of the Aqueous Extract of $P$. daemia}

The extract was prepared the day of the experiment, mimicking strictly the procedures used by the traditional healers. The roots were peeled-off, cut to pieces, and air dried at room temperature. Then, dried root samples were grounded into coarse powder. The powder was added to distilled water $(5 \mathrm{~g}$ in $75 \mathrm{ml}$ ) and boiled for $20 \mathrm{~min}$. Following cooling at room temperature, the solution obtained was filtered with Whatman $\mathrm{N}^{\mathrm{O}} 1$ filter paper. The filtrate was considered as the stock solution. The amount of dry matter in the extract was determined by evaporating water in a drying oven $\left(50^{\circ} \mathrm{C}\right)$. A solid residue $(0.37 \mathrm{~g})$ was obtained. The yield of extraction was $7.34 \%$, and the stock solution dose was $49 \mathrm{mg} / \mathrm{kg}$. The other doses used in the study $(24.5,12.3$, and $4.9 \mathrm{mg} / \mathrm{kg})$ were obtained by dissolving the stock solution in distilled water at ratios of $1 / 2,1 / 4$, and $1 / 10$, respectively.

\section{Animals}

Ninety male or female Swiss albino mice weighting 18-29 g (37-48 days old) were used. They were obtained from Cameroon National Veterinary Laboratory (Lanavet, Garoua, Cameroon) and were housed and bred in the animal facility of the University of Ngaoundere (Ngaoundere, Cameroon). They were kept in a controlled environment, with ad libitum access to food and tap water. Animals were maintained on a $12 \mathrm{~h} / 12 \mathrm{~h}$ light/dark cycle (lights on at 7:00 a.m.). Animals were acclimated to laboratory conditions before starting the experiments. All procedures were performed in conformance with the Cameroon National Ethical Committee directives (Ref No. FW-IRB00001954, October 22, 1987 under an authorization number CEI-UDo/907/01/2017/T). The study was also performed conforming to international regulations minimizing the number of animals used and avoiding their suffering.

\section{In Vivo Studies \\ Experimental Design}

Mice were randomly divided into eight groups of seven animals each. One control group received only distilled water $(\mathrm{DW}+\mathrm{DW}$ group) and in the other seven groups SE was induced by a single injection of pilocarpine hydrochloride $(360 \mathrm{mg} / \mathrm{kg}$, i.p., Sigma-Aldrich). Two hours after SE induction, the following groups were formed: (i) disease group receiving distilled water (10 ml/kg; DW + PILO group); to control the eventual effect of distilled water; (ii) two groups administered either with sodium valproate $(300 \mathrm{mg} / \mathrm{kg}$, Sigma-Aldrich) or vitamin C
(250 mg/kg, Sigma-Aldrich); (iii) four test groups receiving the doses of $P$. daemia extract $(4.9,12.3,24.5$, and $49 \mathrm{mg} / \mathrm{kg}$ ) orally, through an intragastric feeding tube. Treatments were administered daily for 7 days. Twenty-four hours after the last administration of the treatments, mice were challenged with PTZ (Blanco et al., 2009). Then, memory was assessed using the following behavioral paradigms: elevated plus-maze (48-h after treatment) and T-maze (72-h after) (Mehla et al., 2010; Taiwe et al., 2015). Animal behavior was recorded by two blinded experimenters. Afterward, mice were sacrificed by decapitation under deep anesthesia with diethyl ether (8\%, v/v, SigmaAldrich). The brain was dissected out and processed for the quantification of markers of oxidative stress and cholinergic status determination.

\section{SE Induction, Behavioral Observations, and Tests $S E$ induction and seizure evaluation}

Animals were subjected to epileptogenesis induction by a single intraperitoneal injection of pilocarpine (Turski et al., 1983). The minimal dose of chemoconvulsant at which $99 \%$ of the animals showed seizures was determined based on the available reports (Miller and Tainter, 1944; Turski et al., 1983). This was verified by dose-percentage effect curves obtained in our laboratory; the survival rate was $90 \%$. To prevent peripheral muscarinic stimulation, scopolamine (Sigma-Aldrich) was injected subcutaneously at a dose of $1 \mathrm{mg} / \mathrm{kg}, 30 \mathrm{~min}$ before injection of pilocarpine (Liu et al., 2010). About $30 \mathrm{~min}$ after pilocarpine injection, animals became hypoactive and displayed oro-facial movements, salivation, eye blinking, twitching of vibrissae and yawning. Generalized seizure and limbic SE were observed 40-80 min after pilocarpine injection. Only mice that displayed 2-h of SE were selected in this study (Goffin et al., 2007; Curia et al., 2008). SE was stopped after 2-h with an injection of diazepam (10 mg/kg, Roche) in order to prevent mortality. SE initiated by pilocarpine injection triggers epileptogenesis which progress during about 1-2 weeks (Cavalheiro, 1995; Curia et al., 2008). Two hours after SE, animals were treated for 1 week with $P$. daemia extract, sodium valproate and vitamin C. During this period (i.e., the epileptogenesis period) mice were challenged with a convulsant. The challenge was characterized by the acute PTZ administration (Ilhan et al., 2005; Blanco et al., 2009). The challenge with PTZ was used to assess behaviorally the sensibility to a convulsant agent of animals treated or not with the plan extract (Ilhan et al., 2005; Blanco et al., 2009). Then, mice were placed in a $30 \mathrm{~cm} \times 30 \mathrm{~cm}$ chambers for 30 min observation. A progressive evolution of seizure activity was evaluated using a six phase scale (Erakovic et al., 2001): (i) 0 indicated no response; (ii) 1, ear and facial twitching (iii) 2, convulsive waves axially through the body; (iv) 3, myoclonic body jerks; (v) 4 generalized clonic seizures turn over into side position; (vi) 5, generalized seizures with tonic extension episode and SE; and (vii) 6, death (Khalili et al., 2011). The latency and duration of the first myoclonic jerk, clonic seizure and generalized tonic-clonic seizure were measured. Latencies to generalized tonic-clonic seizure were used to calculate the seizure score as follows: $\mathrm{S}=1$ - (control latency/drug seizure latency) (Mehla et al., 2010). 


\section{Elevated plus-maze paradigm}

Cognitive function was assessed using an elevated plus maze. The apparatus is made up of two open arms $(16 \mathrm{~cm} \times 5 \mathrm{~cm})$ and two closed arms $(16 \mathrm{~cm} \times 5 \mathrm{~cm} \times 10 \mathrm{~cm})$ that extend from a common central platform $(5 \mathrm{~cm} \times 5 \mathrm{~cm})$. The entire maze is elevated to a height of $50 \mathrm{~cm}$ above the floor level (Bum et al., 2011). Procedures were performed as previously described (Taiwe et al., 2015). Briefly, in the first task, each animal was placed at the end of the open arm and the initial transfer latency, i.e., the latency to closed arm entry was recorded. A 60 s cut-off was set. The mouse was then allowed to move freely in the maze for another $10 \mathrm{~s}$ (Taiwe et al., 2015). Similarly, 24-h later the latency to closed arm entry, termed retention transfer latency, was determined. Mice which did not enter the enclosed arm within $60 \mathrm{~s}$ on the second trial were assigned a score of $60 \mathrm{~s}$ (Taiwe et al., 2015).

\section{T-maze paradigm}

The T-shaped maze is made of wood and consists of a start arm and two choice arms. Each arm is $30 \mathrm{~cm} \times 10 \mathrm{~cm} \times 20 \mathrm{~cm}$ (length $\times$ width $\times$ height) (Taiwe et al., 2015). A recessed black plastic cup ( $3 \mathrm{~cm}$ in diameter, $1 \mathrm{~cm}$ in depth) containing food was placed on the floor at the end of each choice arm (Taiwe et al., 2015). A day before the experiment, each animal was placed in the start position (at the end of the start arm) for a $10 \mathrm{~min}$ exploration trial, one arm open and the other one closed and at the end, they were returned to their home cage. The following day, animals were reintroduced in the T-maze for a 5 min testing period (Taiwe et al., 2015). During the retrial (the two choice arms were opened), animals were placed in a start arm and the number of visits and the time spent in the two arms were recorded (Taiwe et al., 2015).

\section{Biochemical Tests}

Immediately after the animals were sacrificed, the brain hemispheres were quickly dissected out and cleaned with icecold saline $(0.9 \%, \mathrm{w} / \mathrm{v})$ to remove the hippocampus. After weighing the hippocampi, they were stored at $-43^{\circ} \mathrm{C}$. To perform biochemical analyses, $10 \%(\mathrm{w} / \mathrm{v})$ homogenates prepared with ice-cold $0.1 \mathrm{M}$ phosphate buffer $(\mathrm{pH}$ 7.4) were centrifuged $(10,000 \times g, 15 \mathrm{~min})$. Aliquots of the supernatant were collected and used for biochemical estimation of reduced glutathione (GSH), protein, nitric oxide (NO), and malondialdehyde (MDA) levels. Superoxide dismutase (SOD) and catalase (CAT) activities were also determined from these tissues. Acetylcholinesterase (AchE) activity was assessed in hippocampi dissected from the right hemisphere (Mehla et al., 2010; Taiwe et al., 2015).

\section{Total proteins quantification}

The protein amount was estimated using the Biuret method (Gornall et al., 1949). The BSA (Carlsbad) was used as standard. Briefly, $3 \mathrm{ml}$ of Biuret reagent (Sigma-Aldrich) and $10 \mu \mathrm{l}$ of homogenate were added into test tubes. The contents were mixed by inversion and the absorbance was measured at $590 \mathrm{~nm}$ after 2 min against blank ( $3 \mathrm{ml}$ of $\mathrm{NaCl} 0.9 \%$ mixed with $3 \mathrm{ml}$ of Biuret reagent). The weight of protein was plotted against the corresponding absorbance resulting in a standard curve used to determine the protein in unknown samples. The concentration of protein was expressed in $\mathrm{mg} / \mathrm{ml}$ of protein in the tissue.

\section{AchE activity}

The AchE activity was assessed by the Ellman method (Ellman et al., 1961). The assay mixture contained $0.05 \mathrm{ml}$ of supernatant, $3 \mathrm{ml}$ of sodium phosphate buffer ( $\mathrm{pH} \mathrm{8}$, Sigma-Aldrich), $0.1 \mathrm{ml}$ of acetylthiocholine iodide (Sigma-Aldrich) and $0.1 \mathrm{ml}$ of DNTB (Ellman reagent, Sigma-Aldrich). The change in absorbance was measured at $412 \mathrm{~nm}$ for $2 \mathrm{~min}$, at $30 \mathrm{~s}$ intervals. Results were expressed in $\mathrm{U} / \mathrm{min} / \mathrm{mg}$ of protein in the tissue $(1 \mathrm{U} / \mathrm{min} / \mathrm{mg}$ of AchE was defined as the amount of enzyme that hydrolyzed $1 \mu \mathrm{mol}$ of acetylthiocholine iodide).

\section{SOD activity}

The SOD activity in the tissues was determined by the method of Misra and Fridovich (1972), where the autoxidation of adrenaline (Sigma-Aldrich) is followed in terms of the production of adrenochrome (maximum absorption at $480 \mathrm{~nm}$ ). Tissue homogenates $(134 \mu \mathrm{l})$ were introduced in a test tube and $1666 \mu \mathrm{l}$ of phosphate buffer $(0.05 \mathrm{M}, \mathrm{pH} 10.2)$ in a blank tube to equilibrate the spectrophotometer. The reaction was started by adding $200 \mu \mathrm{l}$ of freshly prepared adrenaline $(0.3 \mathrm{mM})$. Then, the mixture was quickly mixed. The increase in absorbance at $480 \mathrm{~nm}$ was recorded at 20 and $80 \mathrm{~s}$ against the blank. One unit (U) of SOD was defined as the quantity of SOD required to inhibit 50\% of the oxidation of adrenaline in adrenochrome for $1 \mathrm{~min}$. The activity of SOD was expressed in $\mathrm{U} / \mathrm{min} / \mathrm{mg}$ of protein in the tissue.

\section{CAT activity}

The CAT activity was assayed following the method of Sinha (1972). In this method, dichromate (Sigma-Aldrich) in acetic acid (Sigma-Aldrich) is reduced to chromic acetate when heated in the presence of $\mathrm{H}_{2} \mathrm{O}_{2}$. The blue perchromic acid, an unstable intermediate is then formed. The reaction mixture consisted of $187.5 \mu \mathrm{l}$ phosphate buffer $(0.1 \mathrm{M}, \mathrm{pH} 7.5)$ and $12.5 \mu \mathrm{l}$ of homogenate. The reaction was started by adding $50 \mu \mathrm{l}$ of $\mathrm{H}_{2} \mathrm{O}_{2}$ (50 mM, Sigma-Aldrich). After $1 \mathrm{~min}$, the reaction was stopped by the addition of $500 \mu \mathrm{l}$ of dichromate acetic acid reagent. The tubes were immediately kept in a boiling water bath at $100^{\circ} \mathrm{C}$ for $10 \mathrm{~min}$, and the green color developed during the reaction was read at $570 \mathrm{~nm}$ on a spectrophotometer against the blank. Blank tube, devoid of enzyme, was also processed in parallel. The amount of $\mathrm{H}_{2} \mathrm{O}_{2}$ remaining was determined using a standard curve. The enzyme activity was expressed in mmol of $\mathrm{H}_{2} \mathrm{O}_{2}$ consumed $/ \mathrm{min} / \mathrm{mg}$ of protein in brain tissue. The specific activity of CAT was calculated as follows: CAT activity $=[(A$ of sample $A$ of blank $) \times f /(a \times t \times m i)]$. Where $A$ is the absorbance, $f$ the dilution factor, $a$ standard curve coefficient, $t$ the time in minute and $m i$ the weight of tissue processed.

\section{GSH level}

Glutathione was measured using the method of Ellman (1959). Briefly, $1500 \mu \mathrm{l}$ of DNTB and $500 \mu \mathrm{l}$ of Tris-HCl (SigmaAldrich) buffer (50 mM, pH 7.4) were added to a blank tube containing $100 \mu \mathrm{l}$ of Tris- $\mathrm{HCl}$ buffer $(50 \mathrm{mM}, \mathrm{pH} 7.4$ ) or to test tubes containing tissue homogenates $(100 \mu \mathrm{l})$. The mixture solution was incubated for $1 \mathrm{~h}$, and the absorbance was read against the blank at $412 \mathrm{~nm}$. The GSH concentration was calculated using an extinction coefficient of $13600 \mathrm{~mol}^{-1} \mathrm{~cm}^{-1}$. 
The concentration of GSH was expressed as $\mu \mathrm{mol} / \mathrm{g}$ of protein in the tissue.

\section{MDA level}

The method of Wilbur et al. (1949) for MDA determination was used. Briefly, distilled water $(250 \mu \mathrm{l})$ and homogenate $(20 \mu \mathrm{l})$ were introduced in the control tube and in the test tubes, respectively. Then, $250 \mu \mathrm{l}$ of Tris- $\mathrm{HCl}$ buffer $(50 \mathrm{mM}$, $\mathrm{pH} 7.4), 500 \mu \mathrm{l}$ of trichloroacetic acid (20\%, Sigma-Aldrich) and $1000 \mu \mathrm{l}$ of thiobarbituric acid (0.67\%, Sigma-Aldrich) were added. The mixture solution was heated in a water-bath $\left(90^{\circ} \mathrm{C}\right.$, $10 \mathrm{~min})$. After cooling at room temperature, the tubes were centrifuged ( $3000 \mathrm{rpm}, 15 \mathrm{~min}$ ). The absorbance of the pinkcolored supernatant was measured against the blank at $530 \mathrm{~nm}$. The MDA concentration was calculated using an extinction coefficient of $1.56 \times 10^{5} \mathrm{mmol}^{-1} \mathrm{~cm}^{-1}$. MDA level was expressed in $\mu \mathrm{mol} / \mathrm{g}$ of protein in the tissue.

\section{NO level}

Nitric oxide content was assayed by the Griess method (Grand et al., 2001). NO is a compound with a short half-life that is rapidly converted to the stable end products nitrate $\left(\mathrm{NO}_{3}{ }^{-}\right)$ and nitrite $\left(\mathrm{NO}_{2}{ }^{-}\right)$. In this assay, the conversion of nitrate into nitrite is accompanied by color development in the presence of [0.1\% $N$-(1-naphthyl) ethylenediamine dihydrochloride, $1 \%$ sulfanilamide and $2.5 \%$ phosphoric acid) in acidic medium] (Griess reagent, Sigma-Aldrich) (Grand et al., 2001). To estimate the quantity of NO, $200 \mu \mathrm{l}$ of homogenate and $200 \mu \mathrm{l}$ of Griess reagent were introduced in test tubes. The solution was mixed and the absorbance was read at $570 \mathrm{~nm}$ after $10 \mathrm{~min}$. A standard curve $\mathrm{NaNO}_{2}$ was established with a set of serial dilutions of nitrite. Linear regression was done by using the peak area from nitrite standard. The resulting equation was used to calculate the unknown sample concentrations. Results were expressed in $\mathrm{mmol} / \mathrm{g}$ of protein in the tissue.

\section{In Vitro Studies}

Primary cortical neuron cultures were prepared from the cerebral cortex of Wistar rat embryo of 17 days as described previously (Kim et al., 1998). Briefly, pregnant Wistar rats were anesthetized with sodium pentobarbital (30 mg/kg, i.p., Sigma-Aldrich) and sacrificed by cervical dislocation. The cerebral cortex of fetal rats was rapidly removed bilaterally and collected. Tissues were then gently minced using a sterile razor blade and digested in PBS (0.1 M, pH 7.4, Sigma-Aldrich) for $15 \mathrm{~min}$. A Pasteur pipette was used for dissociation of cells (approximately 5-10 times). After centrifugation $(200 \times g$ for $3 \mathrm{~min})$, cells were re-suspended in DMEM (Sigma-Aldrich) supplemented with FBS (15\%, Carlsbad), L-glutamine (2 mM, Sigma-Aldrich), sodium bicarbonate (4.2 mM, Sigma-Aldrich), BSA (0.3 g/l, Sigma-Aldrich), $\beta$-mercaptoethanol (0.1 mM, Sigma-Aldrich), penicillin (1\%, Sanofi Aventis), streptomycin (50 $\mu \mathrm{g} / \mathrm{ml}$, Sanofi Aventis) and grown on $0.1 \%$ poly-L-Lysine (Sigma-Aldrich) coated plates. Cultures were incubated at $37^{\circ} \mathrm{C}$ in a humidified $5 \%$ $\mathrm{CO}_{2}$ atmosphere. To prevent proliferation of non-neuronal cells, cytosine $\beta$-D-arabinofuranoside hydrochloride (10 $\mu \mathrm{M}$, SigmaAldrich) was added 3 days after plating. In all experiments, 11 days mature cells were used.

\section{Cell Viability Assay by MTT}

3-(4,5-Dimethylthiazol-2-yl)-2,5-diphenyltetrazolium bromide test is based on the ability of viable cells to metabolize a tetrazolium salt to formazan blue in the mitochondria (Loveland et al., 1992). The formazan accumulation is proportional to the number of viable cells and inversely proportional to the degree of cytotoxicity (Berridge et al., 2005). Briefly, sample supernatants are inoculated in 96 wells. Cortical cell cultures were treated and incubated with $10 \mu \mathrm{l}$ of aqueous extract of $P$. daemia $(5,10,19,40,77,153,306,615,1225$, $2450 \mu \mathrm{g} / \mathrm{ml}$ ) for $1 \mathrm{~h}$. Cultures were then exposed to L-glutamate (10 mM) and maintained for $24 \mathrm{~h}$ (Kim et al., 1998). After the incubation, culture medium was removed before adding $100 \mu \mathrm{l}$ of solution of MTT (1 mg/ml, Sigma-Aldrich). The plates were incubated during $1 \mathrm{~h}$ at $37^{\circ} \mathrm{C}$. Excess MTT was removed and $100 \mu \mathrm{l}$ of DMSO (0.1\%, Sigma-Aldrich) were added to each well to dissolve formazan crystals (precipitates resulting from the conversion of MTT by the mitochondrial succinate dehydrogenase). The plates were vortexed for $5 \mathrm{~min}$ and read at $540 \mathrm{~nm}$ with a microplate reader. The percentage of cell viability was expressed according to the following formula: percentage of cell viability $=100 \times[$ (optical density $(\mathrm{OD})$ of L-glutamate + extract treated cultures $)$ - (OD of L-glutamate treated cultures $) /(\mathrm{OD}$ of control cultures - OD of L-glutamate treated cultures)] (Koo et al., 2006).

\section{Cell Viability Assay by Lactate Dehydrogenase (LDH)}

Lactate dehydrogenase $(\mathrm{LDH})$ is a cytosolic enzyme present in many different cell types. Plasma membrane damage releases LDH into the cell culture media (Decker and Lohmann-Matthes, 1988). Extracellular LDH in the media can be quantified by a coupled enzymatic reaction in which $\mathrm{LDH}$ catalyzes the conversion of lactate to pyruvate via $\mathrm{NAD}^{+}$reduction to $\mathrm{NADH}$ (Decker and Lohmann-Matthes, 1988). Therefore, NADH is used to reduce a tetrazolium salt to a red formazan product that can be measured at $490 \mathrm{~nm}$ (Nachlas et al., 1960). For the assay $20 \mu \mathrm{l}$ of lactate solution $(36 \mathrm{mg} / \mathrm{ml}$ of $10 \mathrm{mM}$ Tris buffer, $\mathrm{pH}$ 8.5, Sigma-Aldrich) were added to the samples in microliter wells, followed by $20 \mu \mathrm{l}$ solution of MTT $(2 \mathrm{mg} / \mathrm{ml}$ of PBS (0.1 M, pH 7.4) prepared from a 10-fold concentrated stock solution in DMSO). The enzymatic reaction was then started by addition of $20 \mu \mathrm{l}$ of a solution containing $\mathrm{NAD}^{+}$ (3 $\mathrm{mg} / \mathrm{ml}$, Sigma-Aldrich) and diaphorase (13.5 U/ml; BSA: $0.03 \%$; sucrose: $1.2 \%$; in PBS, Sigma-Aldrich) and allowed to proceed for $20 \mathrm{~min}$ (Decker and Lohmann-Matthes, 1988). The reaction was terminated by the addition of $20 \mu \mathrm{l}$ of the LDH inhibitor oxamate $(16.6 \mathrm{mg} / \mathrm{ml}$ of PBS, SigmaAldrich). Measurements were performed at $490 \mathrm{~nm}$ with a microplate reader. Percentage of cell viability was evaluated as above.

\section{Quantification of Apoptosis and Necrosis by Hoechst 33342 and Propidium lodide Staining}

The experiment was realized according to the method described by Syed et al. (2013). Briefly, cells were grown in tissue culture 
dishes and treated with or without the aqueous extract of $P$. daemia at concentrations $(5,10,19,40,77,153,306,615$, $1225,2450 \mu \mathrm{g} / \mathrm{ml})$. After $24 \mathrm{~h}$ of incubation in an incubator $\left(37^{\circ} \mathrm{C}\right.$ in $\left.5 \% \mathrm{CO} 2\right)$, the cells were harvested and washed with cold PBS (0.1 M, pH 7.4). The cells were suspended in Hoechst 33342 solution (10 $\mu \mathrm{g} / \mathrm{ml}$, Sigma-Aldrich) and were incubated $\left(37^{\circ} \mathrm{C}\right.$ in $\left.5 \% \mathrm{CO}_{2}\right)$ for $7 \mathrm{~min}$ (Syed et al., 2013). After incubation with Hoechst 33342, the cells were stained with propidium iodide (2.5 $\mu \mathrm{g} / \mathrm{ml}$, Sigma-Aldrich). The samples were maintained in the dark for $15 \mathrm{~min}$. After staining, an aliquot of cell suspension was placed on a glass microscope slide. The slides were observed immediately under a fluorescence microscope and the fluorescence was measured at $630 \times$ magnification. Cells were counted and the numbers of each of the four cellular states were recorded and analyzed using fluorescence microscopy for quantification of apoptosis and necrosis (Moongkarndi et al., 2004; Syed et al., 2013). The experiment was conducted in triplicates. Hoechst 33342 was used to determine apoptotic nuclear morphology, while propidium iodide indicated dead cells by necrosis. Cells with fragmented or condensed nuclei were considered as apoptotic cells. After the exclusion of the positive apoptotic cells from Hoechst 33342 , the propidium iodide positive cells were considered necrotic cells (Moongkarndi et al,, 2004). The numbers of apoptotic or necrotic cells in the treatment groups were compared to the control. The percentages of apoptotic and necrotic cells were determined according to the following formula:

- Percentage of apoptotic cells $=[(\mathrm{LA}+\mathrm{DA}) / \mathrm{LN}+\mathrm{LA}+$ $\mathrm{DN}+\mathrm{DA}) \times 100]$

- Percentage of necrotic cells $=[(\mathrm{DN} / \mathrm{LN}+\mathrm{LA}+$ $\mathrm{DN}+\mathrm{DA}) \times$ 100] (Brady, 2004; Syed et al., 2013). Where LN are live target cells with normal nuclei (Hoechst 33342/propidium iodide: blue chromatin with organized structure), LA are live cells with apoptotic nuclei (Hoechst 33342/propidium iodide: bright blue chromatin that is highly condensed or fragmented), DN are dead cells with normal nuclei (Hoechst 33342/propidium iodide: pink chromatin with organized structure), and DA are dead cells with apoptotic nuclei (Hoechst 33342/propidium iodide: bright pink chromatin that is highly condensed or fragmented).

\section{Statistical Analysis}

Inter-group differences were assessed using one-way analysis of variance (ANOVA), followed by Newman Keul's multiple comparisons post hoc test. The significance level was set at $p<0.05$, with Mann-Whitney $U$ test correction. Analyses were performed using Graph Pad Prism version 5.1 for Windows (Graph Pad Software, San Diego, CA, United States) and XLSTAT, 2007. Data were expressed as mean \pm standard error of the mean (SEM) for in vivo tests and as percentage for in vitro tests.

\section{RESULTS}

\section{Effects of $\boldsymbol{P}$. daemia on Seizures Induced by PTZ Challenge \\ Latency to Seizures}

The mice treated with PTZ resulted in a classical pattern of limbic motor seizures culminating into generalized tonic-clonic seizures. A decreased myoclonic jerks latency was observed in $\mathrm{DW}+\mathrm{PILO}$ group compared to DW + DW group $(p<0.05)$ (Figure 1A). P. daemia caused a two-fold increase $(p<0.05)$ in the latency to myoclonic jerks compared to DW + PILO group $(37.87 \pm 1.33 \mathrm{~s}$ in DW + PILO group against $77.8 \pm 2.18 \mathrm{~s}$ in the group administered with $P$. daemia dose $24.5 \mathrm{mg} / \mathrm{kg}$ ) $[F(7,49)=23.00, p<0.0001]$ (Figure 1A). Sodium valproate induced an increase of this latency which did not reach statistical significance (Figure 1A).

Latency to clonic seizures was decreased in DW + PILO group compared to DW + DW group $(p<0.05)$ (Figure 1A). P. daemia increased the latency to clonic seizures compared to DW + PILO group $[F(7,49)=121.25, p<0.001]$ (Figure 1A). The latency to clonic seizure increased and reached $165.97 \pm 2.38 \mathrm{~s}$ in the group administered with $P$. daemia dose $24.5 \mathrm{mg} / \mathrm{kg}(p<0.01)$ (Figure 1A). This effect was stronger than sodium valproate effect $(159.92 \pm 2.42 \mathrm{~s}, p<0.05)$ (Figure 1A).

Similarly, a decreased generalized tonic-clonic seizure latency was observed in DW + PILO group compared to DW + DW group $(p<0.01)$ (Figure 1A). P. daemia $(24.5 \mathrm{mg} / \mathrm{kg})$ increased significantly and the latency to generalized tonic-clonic seizures $[F(7,49)=312.14, p<0.001]$, compared to DW + PILO group in a dose dependent manner up to $205.08 \pm 1.25 \mathrm{~s}(p<0.01)$ in the group administered with $P$. daemia dose $24.5 \mathrm{mg} / \mathrm{kg}$. This effect was stronger than sodium valproate $(162.10 \pm 2.97 \mathrm{~s}$, $p>0.05)$ and vitamin $C(173.12 \pm 2.89 \mathrm{~s}, p<0.05)$ effect (Figure 1A).

\section{Seizure Duration}

Significant inter-group differences were observed in the duration of myoclonic jerks $[F(7,49)=1.33, p<0.01]$, clonic seizures $[F(7,49)=2.45, p<0.001]$ and generalized tonic-clonic seizures $[F(7,49)=7.66, p<0.0001]$. P. daemia decreased the duration of myoclonic jerks from $8.44 \pm 1.03 \mathrm{~s}$ in DW + PILO group to $4.00 \pm 0.48 \mathrm{~s}(p<0.05)$ in the group administered with $P$. daemia dose $24.5 \mathrm{mg} / \mathrm{kg}$ (Figure 1B). The duration was slightly decreased from $8.44 \pm 1.03 \mathrm{~s}$ in DW + PILO group to $4.98 \pm 0.73 \mathrm{~s}(p>0.05), 4.94 \pm 0.80 \mathrm{~s}(p>0.05)$ in the groups administered with sodium valproate and vitamin C, respectively (Figure 1B). Generalized tonic-clonic seizures duration was decreased from $12.30 \pm 1.26 \mathrm{~s}$ in DW + PILO group to $9.09 \pm 1.30 \mathrm{~s}(p<0.05)$ and $9.14 \pm 1.36 \mathrm{~s}(p<0.05)$ in the groups administered with $P$. daemia doses 12.3 and $49 \mathrm{mg} / \mathrm{kg}$, respectively (Figure 1B).

\section{Seizure Score}

A significant reduction in seizures score was observed in $\mathrm{DW}+$ PILO group compared to DW + DW group $(p<0.01)$ (Figure 1C). Overall, seizures score between the groups was also 

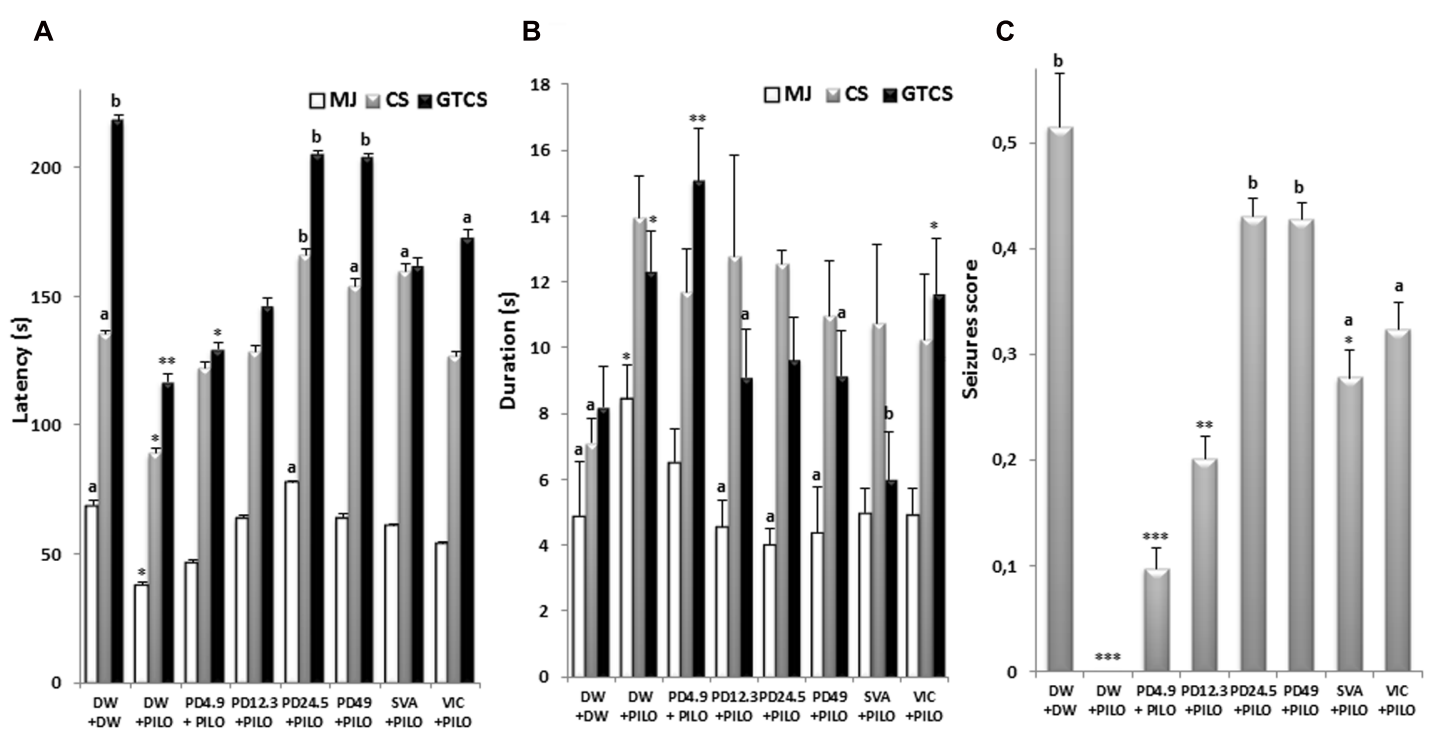

FIGURE 1 | Effect s of $P$. daemia on PTZ challenge outcome. (A) Effects of $P$. daemia extract on the latency to myoclonic jerks, clonic seizures and generalized tonic-clonic seizures induced by pentylenetetrazol challenge in pilocarpine-injected mice. (B) Effect of $P$. daemia extract on the duration of myoclonic jerks, clonic seizures and generalized tonic-clonic seizures in the same animals. (C) Effects of $P$. daemia on the seizures score. Data are mean \pm SEM, $N=7$ per group. Newman Keul's multiple comparisons post hoc test, with Mann-Whitney $U$ test correction: (i) vs. control animals (DW + DW group) receiving only distilled water: ${ }^{*} p<0.05$, ${ }^{* *} p<0.01$; (ii) ${ }^{* * *} p<0.001$ vs. disease control animals (DW + PILO group) receiving distilled water and pilocarpine: ${ }^{a} p<0.05$, ${ }^{b} p<0.01$. CS, clonic seizures; DW, distilled water; MJ, myoclonic jerks; GTCS, generalized tonic-clonic seizures; PD, Pergularia daemia; PILO, pilocarpine; VIC, vitamin C; SVA, sodium valproate.

significantly different $[F(7,49)=73.11, p<0.001]$. P. daemia increased the seizures score from 0 in DW + PILO group to $0.43 \pm 0.02(p<0.01)$ and $0.43 \pm 0.02(p<0.01)$, respectively, in groups treated with $P$. daemia doses 24.5 and $49 \mathrm{mg} / \mathrm{kg}$ (Figure 1C). The seizures score was also increased in groups treated with sodium valproate $(0.28 \pm 0.03, p<0.05)$ and vitamin $\mathrm{C}(0.32 \pm 0.03, p<0.05)$ (Figure 1C).

\section{Effects of $P$. daemia on Memory \\ Elevated Plus Maze}

Significant inter-group differences were observed in the initial transfer latency in the elevated plus maze $[F(7,49)=6.04, p<0.001] . \quad P$. daemia decreased initial transfer latency up to $26.35 \pm 1.56 \mathrm{~s}$ at dose $24.5 \mathrm{mg} / \mathrm{kg}$, against $39.84 \pm 2.60 \mathrm{~s}$ in DW + PILO group $(p<0.05)$ (Figure 2). Intergroup differences were observed in the retention transfer latency $[F(7,49)=5.99, p<0.01]$. P. daemia induced dose-dependent decrease from $36.03 \pm 2.13 \mathrm{~s}$ in $\mathrm{DW}+$ PILO group to $18.84 \pm 2.05 \mathrm{~s}(p<0.01)$ in the group administered with $P$. daemia dose $49 \mathrm{mg} / \mathrm{kg}$ (Figure 2). However, sodium valproate and vitamin $\mathrm{C}$ did not induce significant decreases in initial and retention transfer latencies (Figure 2).

\section{T-maze}

No inter-group difference was observed in the number of entries in the start arm (Figure 3B). P. daemia decreased the time spent in the familiar arm $(14.92 \pm 2.30 \mathrm{~s}$ at dose $24.5 \mathrm{mg} / \mathrm{kg}$ vs. $22.90 \pm 1.44 \mathrm{~s}$ in DW + PILO group, $p<0.05$ ) (Figure 3A). As sodium valproate and vitamin C, $P$. daemia increased the

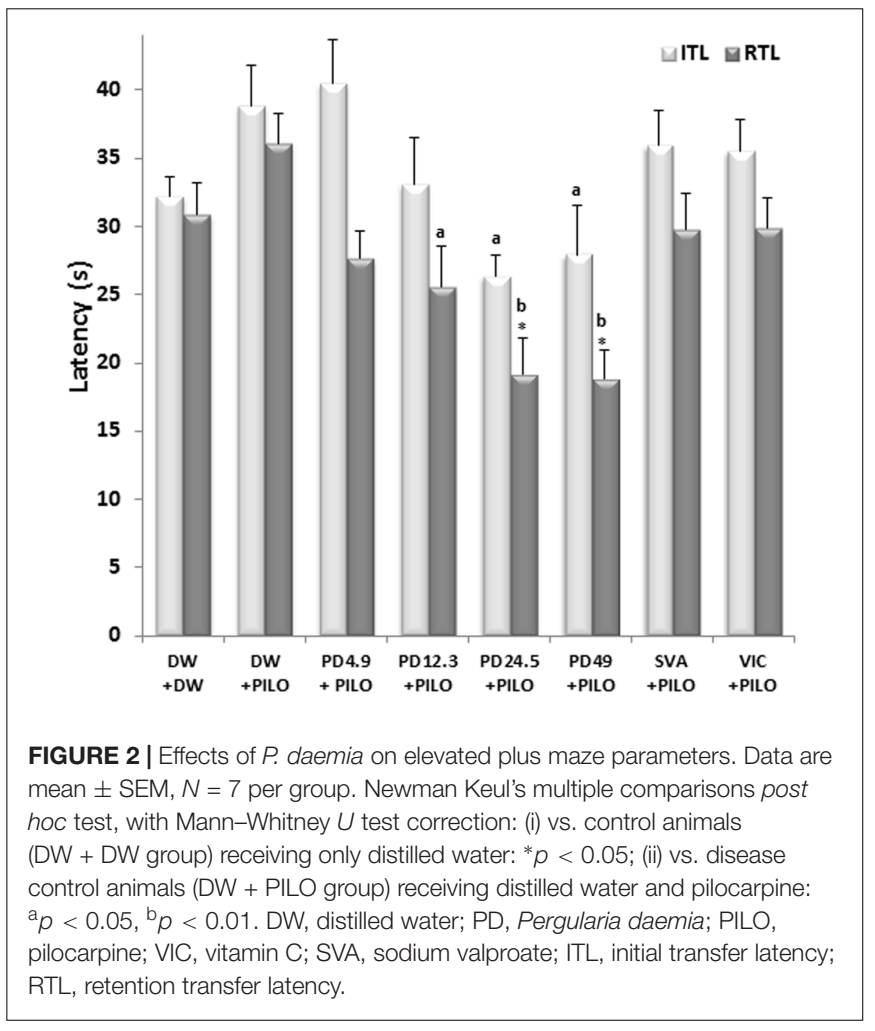

time spent in the novel arm up to $23.16 \pm 2.16 \mathrm{~s}$ at dose $24.5 \mathrm{mg} / \mathrm{kg}$ (against $9.08 \pm 2.24 \mathrm{~s}$ in DW + PILO group, $p<0.01$ ) (Figure 3A). 
A

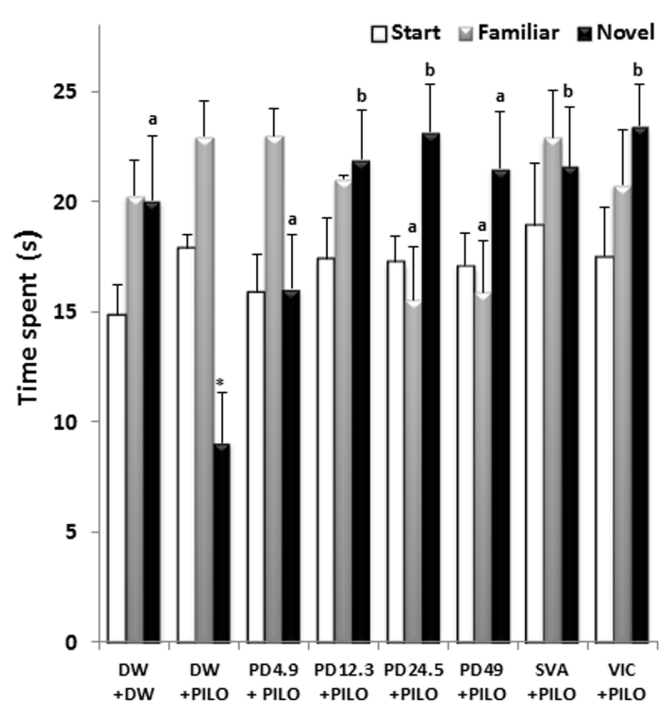

B

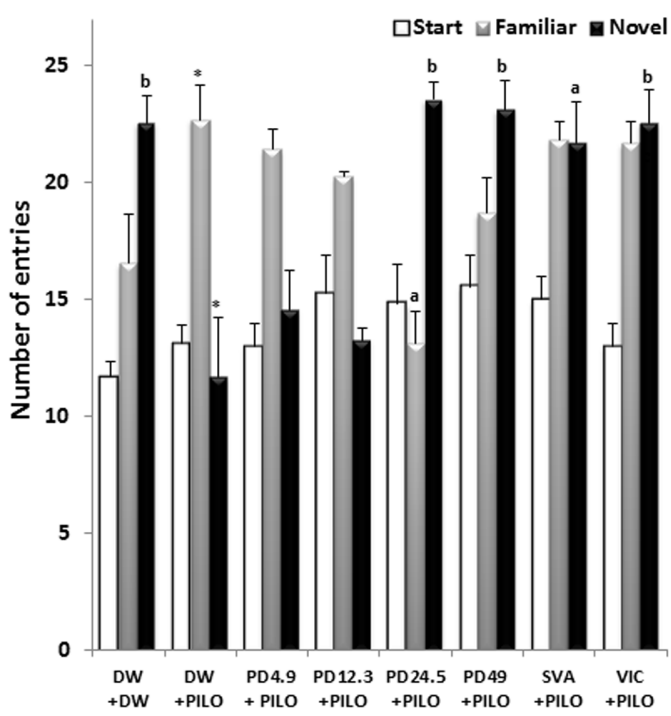

FIGURE 3 | Effects of $P$. daemia on T-maze parameters. (A) Effects of $P$. daemia on the time spent in the start, novel and familiar T-maze. (B) Effect of $P$. daemia on the number of entries in start, novel and familiar T-maze arms. Data are mean $\pm \mathrm{SEM}, N=7$ per group. Newman Keul's multiple comparisons post hoc test, with Mann-Whitney $U$ test correction: (i) vs. control animals (DW + DW group) receiving only distilled water: $* p<0.05$; (ii) vs. disease control animals (DW + PILO group) receiving distilled water and pilocarpine: ${ }^{a} p<0.05,{ }^{b} p<0.01$. DW, distilled water; PD, Pergularia daemia; PILO, pilocarpine; VIC, vitamin C; SVA, sodium valproate.

Similar, no inter-group difference was observed in the number of entries in the start arm (Figure 3B). The number of entries in the familiar arm was decreased up to $13.14 \pm 1.35$ in the group treated with $P$. daemia dose $24.5 \mathrm{mg} / \mathrm{kg}$ (against $22.71 \pm 1.48$ in DW + PILO group, $p<0.05$ ) (Figure $3 \mathrm{~B}$ ). Conversely, the number of entries in novel arm was increased up to $23.57 \pm 0.72(p<0.01)$ and $23.14 \pm 1.22(p<0.01)$ in groups treated with $P$. daemia doses 24.5 and $49 \mathrm{mg} / \mathrm{kg}$, respectively (against $11.71 \pm 2.53$ in DW + PILO group) (Figure 3B). Although in a lesser extent, sodium valproate and vitamin $\mathrm{C}$ also increased the number of entries in the novel arm (Figure 3B).

\section{Levels of Total Proteins, AchE, Antioxidant Enzymes, and Oxidative Stress Markers}

Total Level of Protein

Significant inter-group differences were observed in hippocampus total proteins level $[F(7,49)=130.20$, $p<0.001]$. Pilocarpine significantly decreased the protein level up to $2.29 \pm 0.00 \mathrm{mg} / \mathrm{ml}$ wet tissue in DW + PILO group, against $8.32 \pm 0.00 \mathrm{mg} / \mathrm{ml}$ in the $\mathrm{DW}+\mathrm{DW}$ group $(p<0.01)$ (Figure 4A). Treatment with $P$. daemia prevented such decrease in a dose-dependent manner. At dose $49 \mathrm{mg} / \mathrm{kg}$, the extract resulted in protein level comparable to DW + DW group (7.45 $\pm 0.00, p<0.01$ vs. DW + PILO group) (Figure 4A). The well-established antioxidant vitamin $C$ also prevented pilocarpine-induced protein decrease $(6.60 \pm 0.00, p<0.05$ vs. DW + PILO group) (Figure 4A).

\section{AchE Activity}

Significant inter-group differences were observed in AchE activity $[F(7,49)=244.76, p<0.001]$. Pilocarpine decreased AchE activity compared to DW + DW group $(1.59 \pm 0.00 \mathrm{U} / \mathrm{min} / \mathrm{mg}$ in $\mathrm{DW}+\mathrm{PILO}$ group vs. $12.01 \pm 0.00 \mathrm{U} / \mathrm{min} / \mathrm{mg}, p<0.001)$ (Figure 4B). P. daemia dose $49 \mathrm{mg} / \mathrm{kg}$ prevented the decrease in AchE activity caused by pilocarpine $(7.10 \pm 0.00 \mathrm{U} / \mathrm{min} / \mathrm{mg}$, $p<0.01$ vs. DW + PILO group) (Figure 4B).

\section{Antioxidant Enzymes}

The effects of $P$. daemia extract on activities of the antioxidant enzymes tested (CAT and SOD) in hippocampi of pilocarpineinjected mice is shown in Table 1. P. daemia treatment increased SOD $(p<0.05)$ and CAT $(p<0.01)$ activities compared to DW + PILO group. Vitamin $C$ also increased CAT activity. Although to a lesser extent, sodium valproate also displayed some of these effects, particularly the marked decrease in CAT activity induced by pilocarpine (Table 1).

\section{Oxidative Stress Markers Level}

The effects of $P$. daemia extract on levels of oxidative stress markers tested (GSH, MDA, and NO) in hippocampi of pilocarpine-injected mice is shown in Table 1. $P$. daemia treatment induced moderate increase $(p<0.05)$ in the GSH level compared to DW + PILO group. On the other hand, the extract decreased significantly the MDA level $(p<0.05)$ and, surprisingly, increased the estimated NO level. Although to a lesser extent, sodium valproate also displayed a non-significant decrease in GSH level and MDA level induced by pilocarpine (Table 1). 

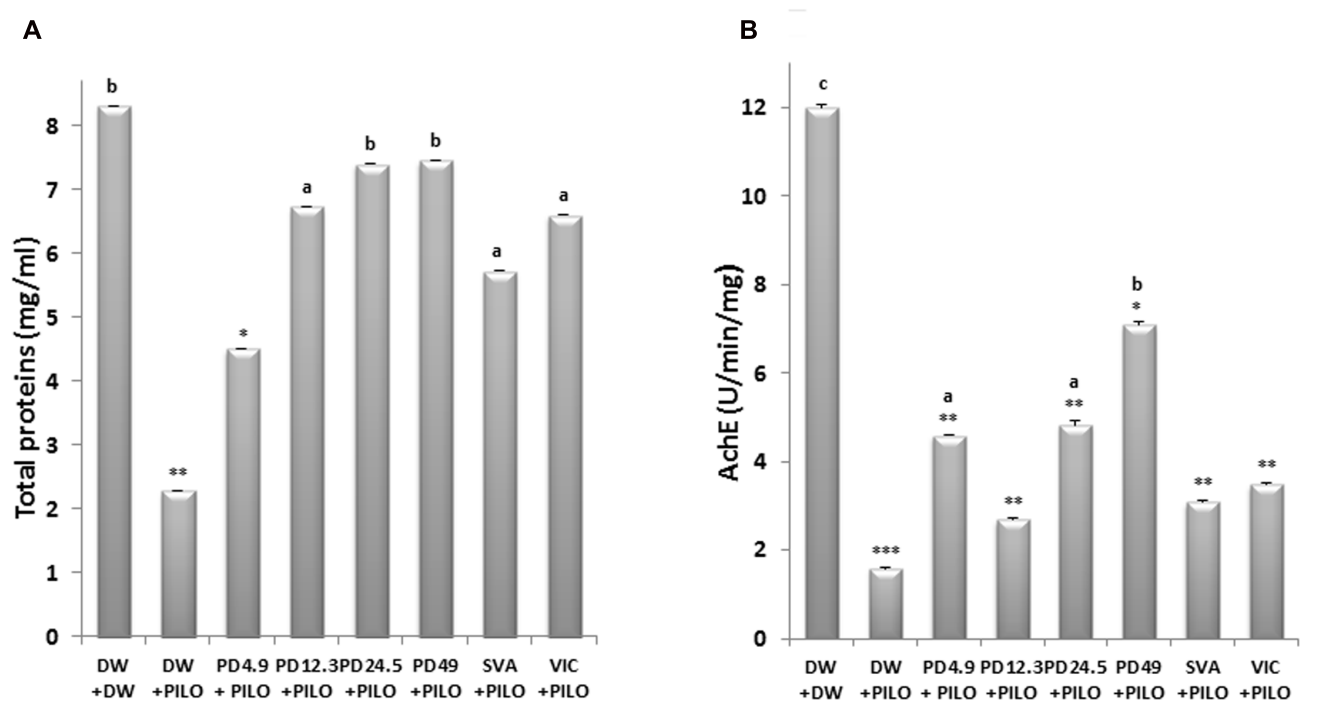

FIGURE 4 | Effects of $P$. daemia on total proteins level and AchE activity. (A) Effects of $P$. daemia on total proteins level in hippocampi of pilocarpine-injected mice. (B) Effect of $P$. daemia on AchE level in hippocampi of the same animals. Data are mean $\pm \mathrm{SEM}, N=7$ per group. Newman Keul's multiple comparisons post hoc test, with Mann-Whitney $U$ test correction : (i) vs. control animals (DW + DW group) receiving only distilled water: ${ }^{*} p<0.05,{ }^{* *} p<0.01,{ }^{* * *} p<0.001$; (ii) vs. disease control animals (DW + PILO group) receiving distilled water and pilocarpine: ${ }^{a} p<0.05,{ }^{b} p<0.01$. DW, distilled water; PD, Pergularia daemia; PILO, pilocarpine; VIC, vitamin C; SVA, sodium valproate.

TABLE 1 | Effects of $P$. daemia on antioxidant enzymes and oxidative stress markers in hippocampi of pilocarpine-injected mice.

\begin{tabular}{|c|c|c|c|c|c|c|}
\hline Treatment & Dose (mg/kg) & MDA $(\mu \mathrm{mol} / \mathrm{g})$ & GSH $(\mu \mathrm{mol} / \mathrm{g})$ & $\operatorname{SOD}(\mathrm{U} / \mathrm{min} / \mathrm{mg})$ & CAT $\left(\mathrm{mmol} \mathrm{H}_{2} \mathrm{O}_{2} / \mathrm{min} / \mathrm{mg}\right.$ ) & $\mathrm{NO}(\mathrm{mmol} / \mathrm{g})$ \\
\hline DW + PILO & -+360 & $0.51 \pm 0.01^{* *}$ & $4.41 \pm 0.02^{*}$ & $12.32 \pm 0.18^{*}$ & $37.32 \pm 0.20^{*}$ & $0.18 \pm 0.00$ \\
\hline $\mathrm{PD}+\mathrm{PILO}$ & $12.3+360$ & $0.44 \pm 0.01^{* *}$ & $10.61 \pm 0.08$ & $12.71 \pm 0.17$ & $48.38 \pm 0.38^{a}$ & $0.19 \pm 0.10$ \\
\hline PD + PILO & $24.5+360$ & $0.21 \pm 0.00 * \mathrm{a}$ & $10.60 \pm 0.09$ & $15.79 \pm 0.10^{a}$ & $77.29 \pm 0.26^{* b}$ & $0.18 \pm 0.02$ \\
\hline PD + PILO & $49+360$ & $0.28 \pm 0.01^{* a}$ & $11.35 \pm 0.13^{\mathrm{a}}$ & $16.87 \pm 0.03^{* a}$ & $107.80 \pm 0.49^{* * b}$ & $0.26 \pm 0.12^{* a}$ \\
\hline VIC + PILO & $250+360$ & $0.36 \pm 0.01^{*}$ & $9.36 \pm 0.12$ & $14.41 \pm 0.21^{a}$ & $102.18 \pm 0.91^{* * b}$ & $0.13 \pm 0.04$ \\
\hline
\end{tabular}

Data are mean $\pm S E M, N=7$ per group. Newman Keul's multiple comparisons post hoc test, with Mann-Whitney $U$ test correction: (i) vs. control animals (DW + DW group) receiving only distilled water: ${ }^{*} p<0.05,{ }^{* *} p<0.01$, (ii) vs. disease control animals (DW + PILO group) receiving distilled water and pilocarpine: 0.05 a $p<0.05$, ${ }^{\mathrm{b}} p<0.01$. DW, distilled water; PD, Pergularia daemia; PILO, pilocarpine; VIC, vitamin C; SVA, sodium valproate; MDA, malondialdehyde; GSH, reduced glutathione; $S O D$, superoxide dismutase; CAT, catalase; NO, nitric oxide.

\section{In Vitro Neuroprotective Effects of P. daemia \\ Protective Effect of $P$. daemia Extract against L-Glutamate-Induced Neurotoxicity}

In the MTT test, stimulation with L-glutamate alone resulted in a decrease in cell viability up to approximately $0.19 \%$ compared to control. Nevertheless, the different doses of the extract exhibited a significant decrease of L-glutamate-induced toxicity in a dose dependent manner. The highest concentration of the extract exhibited protective effect ( $85.92 \%$ vs. control) (Figure 5A). The protective effect of $P$. daemia was also revealed by $\mathrm{LDH}$ release assay. As shown in Figure $\mathbf{5 A}$, cell viability decreased up to approximately $0.39 \%$ after exposure to L-glutamate. However, treatment with $P$. daemia resulted in a significant increase of this viability up to $73.01 \%$ at the highest concentration.

\section{Protective Effect of $P$. daemia against L-Glutamate-Induced Apoptosis and Necrosis}

Results of Hoechst staining in control culture indicated that, after exposure to L-glutamate, cortical neurons exhibited high levels of condensed chromatin and apoptotic bodies, indicating an increase of apoptotic cells up to $93.00 \%$ (Figure 5B). Treatment with $P$. daemia resulted in a significant decrease of these apoptotic features up to $19.67 \%$ at the highest concentration (Figure 5B). Results of propidium iodine staining in control culture indicated that, after exposure to L-glutamate, cortical neurons culture exhibited high levels of degenerated neurons, indicating an increase of necrotic cells up to $89.67 \%$ (Figure 5B). P. daemia was not able to protect neurons against L-glutamate induced cell necrosis (Figure 5B). 

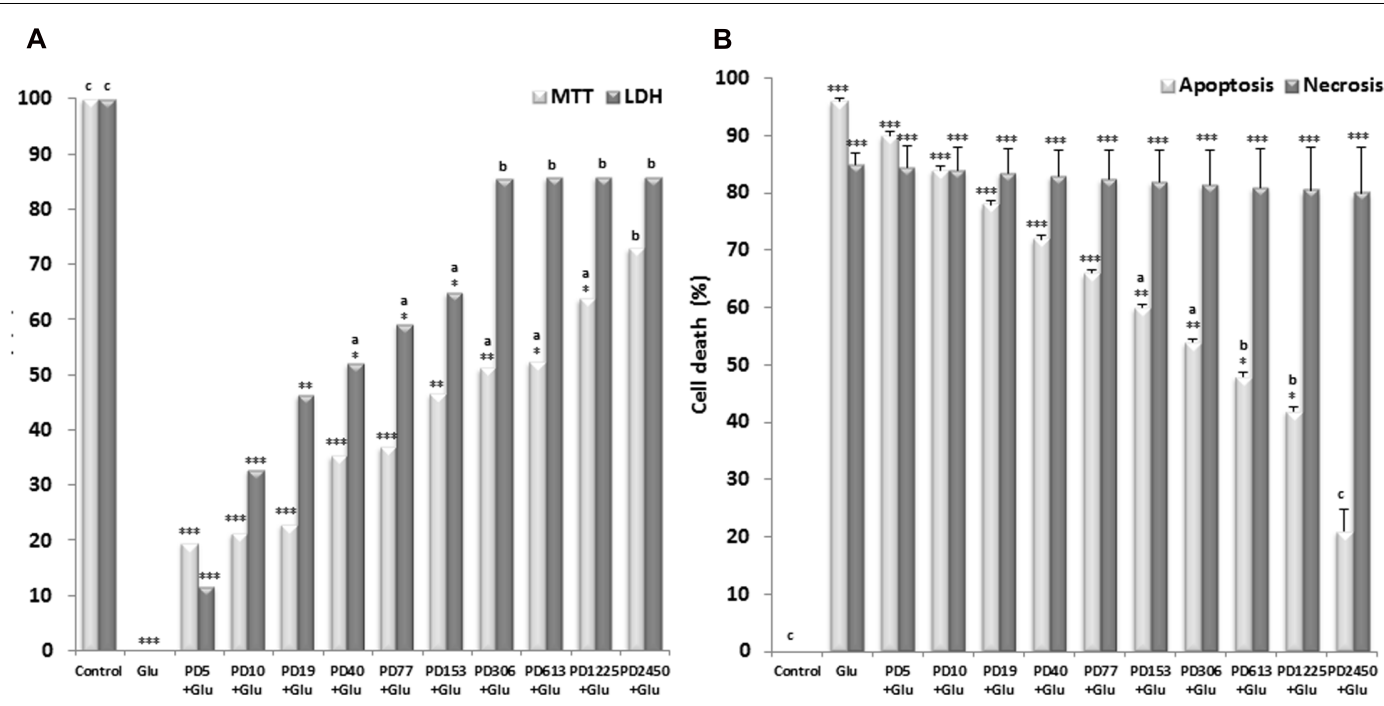

FIGURE 5 | Effects of $P$. daemia against L-glutamate-induced neurotoxicity, apoptosis and necrosis. (A) Effects of $P$. daemia against L-glutamate-induced neurotoxicity. (B) Effects of $P$. daemia against L-glutamate-induced apoptosis and necrosis. Quantitative analysis of the histograms expressed as the percentage of cell viability or cell death by apoptosis and necrosis. Data are mean \pm SEM. Newman Keul's multiple comparisons post hoc test, with Mann-Whitney $U$ test correction : (i) vs. control: ${ }^{*} p<0.05,{ }^{* *} p<0.01$, ${ }^{* * *} p<0.001$; (ii) vs. L-glutamate: ${ }^{a} p<0.05,{ }^{b} p<0.01,{ }^{c} p<0.001$. PD, Pergularia daemia (5, 10, 19, 40, 77, 153, 306, 615, 1225, 2450 мg/ml); MTT, 3-(4,5-dimethylthiazol-2-yl)-2,5-diphenyl tetrazolium bromide; LDH, lactate dehydrogenase; Glu, L-glutamate (10 mM); PD, Pergularia daemia $(5,10,19,40,77,153,306,615,1225,2450 \mu \mathrm{g} / \mathrm{ml})$.

\section{DISCUSSION}

The aim of this study was to evaluate the antiepileptogenic and neuroprotective effects of the decoction of $P$. daemia roots. In vivo and in vitro experimental models were used. As the results show, the acute administration of PTZ in mice treated with distilled water (DW + PILO group) for 1 week (epileptogenesis period) after SE, induced an increase in the latency of seizures, and a decrease in the duration and score of seizures (Blanco et al., 2009). Remarkably, our results demonstrate that PTZ produces different effects when injected in epileptogenic and non-epileptogenic mice. This is a significant demonstration that the pharmacologic response outline of acute seizures contrasts from that of chronic seizures paradigms (Loscher et al., 1991; Blanco et al., 2009). In the present study, $P$. daemia reduced the severity of seizures induced by PTZ challenge on epileptogenic process. P. daemia extract also increased the seizure score dose dependently. Such reduction in seizure severity and in seizure susceptibility to a convulsant during epileptogenesis process suggests that the decoction antagonized or altered the epileptogenic process induced by pilocarpine (Pitkanen et al., 2005; Mehla et al., 2010; Pitkanen, 2010). Indeed, the PTZ $\left(\mathrm{GABA}_{\mathrm{A}}\right.$ receptor complex antagonist) is known to increase the seizure threshold and therefore to induce more severe seizures in epileptogenic brain compared to non-epileptogenic brain (Ilhan et al., 2005; Blanco et al., 2009; Mehla et al., 2010; Taiwe et al., 2015). Thus, the challenge is used to test behaviorally the susceptibility to a convulsant agent with or without treatment with the plant extract (Ilhan et al., 2005; Blanco et al., 2009). The findings of the present study suggest therefore that the aqueous extract of $P$. daemia has antiepileptogenic effects in mouse model of TLE. The effects of $P$. daemia on seizures induced by PTZ were more marked than those of vitamin C (powerful antioxidant), which was previously reported to mitigate epileptogenesis by blocking the efflux, rather than influx, of calcium, and therefore it interferes with these mechanisms (Xavier et al., 2007; dos Santos et al., 2011). These observations suggest that the extract of $P$. daemia could interfere with the mechanisms of neurotransmitter release and/or uptake from neuronal terminals. The effects of $P$. daemia were also more marked than those of the antiepileptic drug sodium valproate. The main mechanisms of valproate include an increase in GABAergic activity, reduction in excitatory neurotransmission and modification of monoamines (Xavier et al., 2007; Loscher and Brandt, 2010; Rahmati et al., 2013; Taiwe et al., 2015). These observations suggest that $P$. daemia could have altered the epileptogenesis process by increasing GABAergic activity and by reducing excitatory neurotransmission. The antioxidant and anticonvulsant effects of the plant probably mediated by different molecules or mechanisms could have as result a synergic effect greater than the effect of Vitamin C or sodium valproate alone.

Furthermore, $P$. daemia extract improved cognitive processes as revealed by the elevated plus maze and T-Maze. Considering that cognitive impairment or decline can also be associated with epileptogenesis in TLE (Cha et al., 2002; Stafstrom, 2006; Kumar et al., 2008; Mehla et al., 2010; Pahuja et al., 2013), these findings further suggest that $P$. daemia extract has antiepileptogenic effects.

The loss of neurons in the hippocampus is the first event characterizing epileptogenesis. This loss of neurons is associated with a significant decrease in total proteins 
(Dalby and Mody, 2001; Yamamoto and Mohanan, 2003; Patsoukis et al., 2005; Waldbaum and Patel, 2010). Given that $P$. daemia prevented the decrease in total proteins induced by pilocarpine, these results suggest that $P$. daemia has neuroprotective effects (Bahndari et al., 2008; Waldbaum and Patel, 2010). Interestingly, the drastic decrease in AchE activity, marker of neuronal loss (Cavazos and Sutula, 1990; Duysen et al., 2002; Veerendra and Gupta, 2002; Freitas et al., 2005; Niessen et al., 2005), was prevented by $P$. daemia. These results also suggest that $P$. daemia has neuroprotective effects. In addition, these effects were more marked than those of vitamin $C$ and valproate sodium. These drugs are known to prevent neuronal loss by preventing oxidative stress (Xavier et al., 2007; dos Santos et al., 2011) and by increasing GABA neurotransmission (Brandt et al., 2003; Loscher and Brandt, 2010), respectively. Altogether, these observations suggest that $P$. daemia antiepileptogenic effects are mediated by neuroprotective effects.

To confirm the implication of antioxidant pathways in the realization of antiepileptogenic effects of $P$. daemia, the effects of the extract on antioxidant enzymes and oxidative stress markers in the hippocampus were assessed. In the present study, the activity of SOD enzyme, which protects cells against harmful superoxide radicals and the resulting oxidative stress (Agarwal et al., 2011; Shin et al., 2011), was drastically increased in groups receiving the extract. The activity of CAT enzyme, which eliminate $\mathrm{H}_{2} \mathrm{O}_{2}$ and its toxic radicals resulting from the antioxidant action of SOD (Freitas et al., 2005; Karthishwaran and Mirunalini, 2012; Kiasalari et al., 2013), was also increased in groups treated with $P$. daemia, in dose dependent manner. These results suggest that the extract induced its antioxidant activities by increasing SOD and CAT activities (Karthishwaran and Mirunalini, 2012; Kiasalari et al., 2013).

Furthermore, decrease in level of MDA, a lipid peroxidation marker caused by free radicals (Dal-Pizzol et al., 2000; Ilhan et al., 2005; Balaji et al., 2013), was also observed. P. daemia treatment increased significantly the tissue levels of GSH, an endogenous antioxidant that reacts with free radicals and prevents the generation of hydroxyl radical (Schulz et al., 2000; Gupta et al., 2003; Agarwal et al., 2011). Altogether, these results also suggest that $P$. daemia antioxidant activity is mediated in part by the decrease in the MDA level and by the increase in the GSH level. These results are in agreement with a report by Bhaskar and Balakrishnan (2009) in which $P$. daemia decreased the MDA level and increased the GSH level. However, the level of NO, whose radicals cause oxidative damage via lipid peroxidation (Ilhan et al., 2005; Khadrawy et al., 2013), was not improved in the present study. This result suggests that $P$. daemia antioxidant activity is not mediated by the inhibition of NO production. This result is in agreement with the study reported by Balaji et al. (2013). Overall, changes in the levels of antioxidant enzymes and oxidative stress markers observed strongly suggest that $P$. daemia extract has antioxidant properties. These properties were more effective than those of vitamin $\mathrm{C}$, a powerful antioxidant known to increase the SOD and CAT activities, and to decrease the MDA level by scavenging free radicals (Xavier et al., 2007; dos Santos et al.,
2011). Taken together, these results suggest that $P$. daemia antiepileptogenic effects are partly mediated by its antioxidant properties.

Neuronal cell death is a pathophysiological consequence of many brain insults that induced epilepsy (Henshall and Engel, 2013). This event is implicated as a causal factor in epileptogenesis (Henshall and Engel, 2013). Overactivation of glutamate receptors under pathophysiological conditions leads to excitotoxic cell death (Meldrum, 2002; Brown and Bal-Price, 2003). The present findings show that $P$. daemia significantly protected cortical neurons against excitotoxicity induced by L-glutamate. These results suggest that $P$. daemia has neuroprotective effects mediated in part by antiapoptotic mechanisms (Narkilahti et al., 2003; Gandhi and Abramov, 2012). Thus, these results explain and confirm antiepileptogenic and neuroprotective effects of $P$. daemia extract in vivo.

\section{CONCLUSION}

In this study, we investigated the antiepileptogenic and neuroprotective effects of aqueous extract of $P$. daemia using in vivo and in vitro approaches. In in vivo studies, oral administration of the extract resulted in reduction in the severity of seizures and cognitive impairment. The study of AchE activity and oxidative stress markers revealed that $P$. daemia extract may mediate its antiepileptogenic effects at least partly through its antioxidant properties. In in vitro studies $P$. daemia protected cells against death induced by L-glutamate. This effect may be mediated by antiapoptotic pathways. Taken together, these findings indicate that $P$. daemia has antiepileptogenic and neuroprotective effects. Future experiments aimed at characterizing further the antiepileptogenic properties of $P$. daemia extract should be designed, considering the therapeutic potential for TLE. This plant could exert some beneficial effect in the threshold of seizures and could be used as complementary treatment for epilepsy and other neurological diseases.

\section{AUTHOR CONTRIBUTIONS}

AK, SP, and GT performed all behavioral studies, accomplished the data analysis and drafted the manuscript. AK, EN, SP, and GT designed the study. EN critically revised the manuscript for important intellectual content. FM, GNg, GNk, JN, JO, SP, and NK helped in in vivo studies. All authors have read and approved the final manuscript.

\section{ACKNOWLEDGMENTS}

The authors are very thankful to Smartox Biotechnologies (France), the University of Ngaoundéré (Cameroon) and the University of Buea (Cameroon). The authors are also thankful Rosette Megnekou, Paul Desire Djomeni Dzeufiet, Paul Etet Seke and Danielle Bilanda for their kindly assistance. 


\section{REFERENCES}

Agarwal, N., Nitin, K., Pramod, K., and Sharma, K. (2011). Effect of lamotrigine, oxcarbazepine and topiramate on cognitive functions and oxidative stress in PTZ-kindled mice. Seizure 20, 257-262. doi: 10.1016/j.seizure.2010.12.006

Ahmadiani, A., Mandgary, A., and Sayyah, M. (2003). Anticonvulsant effect of flutamide on seizures induced by pentylenetetrazole: involvement of benzodiazepine receptors. Epilepsia 44, 629-635. doi: 10.1046/j.1528-1157. 2003.36402.x

Arbonnier, M. (2002). Trees, shrubs and lianas of dryland West Africa. CIRAD 2:573.

Azam, F., El-gnidi, B. A., and Alkskas, I. A. (2010). Combating oxidative stress in epilepsy: design, synthesis, quantum chemical studies and anticonvulsant evaluation of 1-(substituted benzylidene/ethylidene)-4(naphthalen-1-yl) semicarbazides. Eur. J. Med. Chem. 45, 2817-2826. doi: 10.1016/j.ejmech.2010.02.063

Bahndari, U., Ansari, M. N., Islam, F., and Tripathi, C. D. (2008). The effect of aqueous extract of Embelia ribes Burm on serum homocysteine, Lipids and oxidative enzymes in methionine induced hyperhomocysteinemia. Indian J. Pharmacol. 40, 152-157. doi: 10.4103/0253-7613.43161

Balaji, K., Manasa, G., Reddy, A. A., Nagaraju, M., Srikanth, T., and Ramesh, S. (2013). Evaluation of in vitro anti-oxidant and cytotoxicity activity of aqueous extract of Pergularia daemia. Sch. Acad. J. Pharm. 2, 125-129.

Berridge, M. V., Patries, M. H., and Tan, A. S. (2005). Tetrazolium dyes as tools in cell biology: new insights into their cellular reduction. Biotechnol. Ann. Rev. 11, 127-152. doi: 10.1016/S1387-2656(05)11004-7

Bhaskar, V. H., and Balakrishnan, N. (2009). Veliparuthi (Pergularia daemia (Forsk.) Chiov.) as a phytomedicine: a review. Int. J. Pharm. Tech. Res. 1, 1305-1313.

Blanco, M. M., Dos Santos, J. G., Perez-Mendes, P., Kohe, S. R., Cavarsan, C. F., Hummel, M., et al. (2009). Assessment of seizure susceptibility in pilocarpine epileptic and nonepileptic Wistar rats and of seizure reinduction with pentylenetetrazole and electroshock models. Epilepsia 50, 824-831. doi: 10.1111/j.1528-1167.2008.01797.x

Brady, H. J. M. (2004). Apoptosis Methods and Protocols. Totowa, NJ: Humana Press, doi: 10.1385/1592598129

Brandt, C., Glien, M., Potschka, H., Volk, H., and Löscher, W. (2003). Epileptogenesis and neuropathology after different types of status epilepticus induced by prolonged electrical stimulation of the basolateral amygdala in rats. Epilepsy Res. 55, 83-103. doi: 10.1016/S0920-1211(03)00114-1

Brown, G. C., and Bal-Price, A. (2003). Inflammatory neurodegeneration mediated by nitric oxide, glutamate, and mitochondria. Mol. Neurobiol. 27, 325-355. doi: $10.1385 / \mathrm{MN}: 27: 3: 325$

Bum, E. N., Soudi, S., Ayissi, E. R., Dong, C., Lakoulo, N. H., Maidawa, F., et al. (2011). Anxiolytic activity evaluation of four medicinal plants from Cameroon. Afr. J. Tradit. Complement. Altern. Med. 8(Suppl. 5), 130-139. doi: 10.4314/ ajtcam.v8i5S.19

Cavalheiro, E. A. (1995). The pilocarpine model of epilepsy. Ital. J. Neurol. Sci. 16, 33-37. doi: 10.1007/BF02229072

Cavazos, J. E., and Sutula, T. P. (1990). Progressive neuronal loss induced by kindling: a possible mechanism for mossy fiber synaptic reorganization and hippocampal sclerosis. Brain Res. 527, 1-6. doi: 10.1016/0006-8993(90)91054-K

Cha, B. H., Silveira, D. C., Liu, X., Hu, Y., and Holmes, G. L. (2002). Effect of topiramate following recurrent and prolonged seizures during early development. Epilepsy Res. 51, 217-232. doi: 10.1016/S0920-1211(02)00157-2

Curia, G., Longo, D., Biagini, G., Jones, R. S. G., and Avoli, M. (2008). The pilocarpine model of temporal lobe epilepsy. J. Neurosci. Methods 172, 143-157. doi: 10.1016/j.jneumeth.2008.04.019

Dalby, N. O., and Mody, I. (2001). The process of epileptogenesis: a pathophysiological approach. Curr. Opin. Neurol. 14, 187-192. doi: 10.1097/ 00019052-200104000-00009

Dal-Pizzol, F., Klamt, F., Vianna, M. M., Schröder, N., Quevedo, J., Benfato, M. S., et al. (2000). Lipid peroxidation in hippocampus early and late after status epilepticus induced by pilocarpine or kainic acid in Wistar rats. Neurosci. Lett. 291, 179-182. doi: 10.1016/S0304-3940(00)01409-9

Decker, T., and Lohmann-Matthes, M. L. A. (1988). Quick and simple method for the quantitation of lactate dehydrogenase release in measurements of cellular cytotoxicity and tumor necrosis factor (TNF) activity. J. Immunol. Methods 115, 61-69. doi: 10.1016/0022-1759(88)90310-9

dos Santos, P. S., Costa, J. P., da Rocha Tomé, A., Saldanha, G. B., de Souza, G. F., Feng, D., et al. (2011). Oxidative stress in rat striatum after pilocarpineinduced seizures is diminished by alpha-tocopherol. Eur. J. Pharmacol. 668, 65-71. doi: 10.1016/j.ejphar.2011.06.035

Duysen, E. G., Stribley, J. A., Fry, D. L., Himichs, S. H., and Lockridge, O. (2002). Rescue of the acetylcholinesterase knockout mouse by feeding a liquid diet; phenotype of the adult acetylcholinesterase deficient mouse. Brain Res. 137, 43-54. doi: 10.1016/S0165-3806(02)00367-X

Ellman, G. L. (1959). Tissue sulfhydryl groups. Arch. Biochem. Biophys. 82, 70-77. doi: 10.1016/0003-9861(59)90090-6

Ellman, G. L., Courtney, K. D., Andres, V., and Featherstone, R. M. (1961). A new and rapid colorimetric determination of acetylcholinesterase activity. Biochem. Pharmacol. 7, 88-95. doi: 10.1016/0006-2952(61)90145-9

Emerit, J., Edeas, M., and Bricaire, F. (2004). Neurodegenerative diseases and oxidative stress. Biomed. Pharmacother. 58, 39-46. doi: 10.1016/j.biopha.2003. 11.004

Erakovic, V., Zupan, G., Varljen, J., Laginja, J., and Simonic, A. (2001). Altered activities of rat brain metabolic enzymes caused by pentylenetetrazole kindling and pentylenetetrazole-induced seizures. Epilepsy Res. 43, 165-173. doi: 10.1016/S0920-1211(00)00197-2

Freitas, R. M., Vasconcelos, S. M., Souza, F. C., Viana, G. S., and Fonteles, M. M. (2005). Oxidative stress in the hippocampus after pilocarpine-induced status epilepticus in Wistar rats. FEBS J. 272, 1307-1312. doi: 10.1111/j.1742-4658. 2004.04537.x

Gandhi, S., and Abramov, A. Y. (2012). Mechanism of oxidative stress in neurodegeneration. Oxid. Med. Cell Longev. 2012:428010. doi: 10.1155/2012/ 428010

Gilani, A. H., and Rahman, A. (2005). Trends in ethnopharmacology. J. Ethnopharmacol. 100, 43-49. doi: 10.1016/j.jep.2005.06.001

Goffin, K., Nissinen, J., Van Laere, K., and Pitkanen, A. (2007). Cyclicity of spontaneous recurrent seizures in pilocarpine model of temporal lobe epilepsy in rat. Exp. Neurol. 205, 501-505. doi: 10.1016/j.expneurol.2007. 03.008

Gornall, A. C., Bardawill, C. J., and David, M. M. (1949). Determination of serum proteins by means of the Biuret reaction. J. Biol. Chem. 177, 751-766.

Grand, F., Guitton, J., and Goudable, J. (2001). Optimisation des paramètres du dosage des nitrites et nitrates sériques par la technique de Griess. Ann. Biol. Clin. 59, 559-565.

Gupta, Y. K., Veerendra, M. H., and Srivastava, A. K. (2003). Effect of Centella asiatica on pentylenetetrazole-induced kindling, cognition and oxidative stress in rats. Pharmacol. Biochem. Behav. 74, 579-585. doi: 10.1016/S0091-3057(02) 01044-4

Henshall, D. C., and Engel, T. (2013). Contribution of apoptosisassociated signaling pathways to epileptogenesis: lessons from $\mathrm{Bcl}-2$ family knockouts. Front. Cell. Neurosci. 7:110. doi: 10.3389/fncel.2013. 00110

Ilhan, A., Gurel, A., Armutcu, F., Kamilsi, S., and Iraz, M. (2005). Antiepileptogenic and antioxidant effects of Nigella sativa oil against pentylenetetrazol-induced kindling in mice. Neuropharmacology 49, 456-464. doi: 10.1016/j.neuropharm. 2005.04.004

Kan, A. A., van der Hel, W. S., Kolk, S. M., Bos, I. W., Verlinde, S. A., van Nieuwenhuizen, O., et al. (2012). Prolonged increase in rat hippocampal chemokine signalling after status epilepticus. J. Neuroimmunol. 245, 15-22. doi: 10.1016/j.jneuroim.2012.01.012

Karthishwaran, K., and Mirunalini, S. (2010). Therapeutic potential of Pergularia daemia (Forsk.): the Ayurvedic wonder. Int. J. Pharm. 6, 836-843. doi: 10.3923/ ijp.2010.836.843

Karthishwaran, K., and Mirunalini, S. (2012). Assessment of the antioxidant potential of Pergularia daemia (Forsk.) extract in vitro and in vivo experiments on hamster buccal pouch carcinogenesis. Asian Pac. J. Trop. Dis. 2, S509-S516. doi: 10.1016/S2222-1808(12)60212-6

Khadrawy, Y. A., AboulEzz, H. S., Ahmed, N. A., and Mohammed, H. S. (2013). The anticonvulant effect of cooling in comparison to $\alpha$-lipoic acid: a neurochemical study. Neurochem. Res. 38, 906-915. doi: 10.1007/s11064-0130995-2 
Khalili, M., Kiasalari, Z., Roghani, M., and Azizi, Y. (2011). Anticonvulsant and antioxidant effect of hydro-alcoholic extract of Cyperus rotundus rhizome on pentylentetrazole-induced kindling model in male mice. J. Med. Plants Res. 5, 1140-1146.

Kiasalari, Z., Mohsen, K., Mehrdad, R., Hamid, H., and Yaser, A. (2013). Antiepileptic and antioxidant effect of hydroalcoholic extract of Ferula assafoetida gum on pentylentetrazole-induced kindling in male mice. Basic Clin. Neurosci. 4, 299-306.

Kim, Y. C., Kim, S. R., Markelonis, G. J., and Oh, T. H. (1998). Ginsenoside $\mathrm{Rb} 1$ and $\mathrm{Rg} 3$ protect cultured rat cortical cells from glutamate-induced neurodegeneration. J. Neurosci. Res. 53, 426-432. doi: 10.1002/(SICI)1097-4547

Koo, K. A., Seung, H. K., Mi, K. L., and Young, C. K. (2006). 15Methoxypinusolidic acid from Biota orientalis attenuates glutamate-induced neurotoxicity in primary cultured rat cortical cells. Toxicol. In Vitro 20, 936-941. doi: 10.1016/j.tiv.2006.02.001

Kumar, A., Sehgal, N., Kumar, P., Padi, S. S., and Naidu, P. S. (2008). Protective effect of quercetin against ICV colchicine-induced cognitive dysfunctions and oxidative damage in rats. Phytother. Res. 22, 1563-1569. doi: 10.1002/ptr.2454

Kwan, P., and Brodie, M. J. (2003). Clinical trials of antiepileptic medications in newly diagnosed patients with epilepsy. Neurology 60, 2-12. doi: 10.1212/WNL. 60.11_suppl_4.S2

Liu, J., Wang, A., Li, L., Huang, Y., Xue, P., and Hao, A. (2010). Oxidative stress mediates hippocampal neuron death in rats after lithium-pilocarpine-induced status epilepticus. Seizure 19, 165-172. doi: 10.1016/j.seizure.2010.01.010

Lokesh, T. N. (2009). Central nervous system depressant activity of alcohol and aqueous root extracts of Pergularia daemia (Forsk.). Pharmacologyonline 1, 119-124.

Loscher, W., and Brandt, C. (2010). Prevention or modification of epileptogenesis after brain insults: experimental approaches and translational research. Pharmacol. Rev. 62, 668-700. doi: 10.1124/pr.110.003046

Loscher, W., Fassbender, C. P., and Nolting, B. (1991). The role of technical, biological and pharmacological factors in the laboratory evaluation of anticonvulsant drugs. II. Maximal electroshock seizure models. Epilepsy Res. 8, 79-94. doi: 10.1016/0920-1211(91)90075-Q

Loveland, B. E., Johns, T. G., Mackay, I. R., Vaillant, F., Wana, Z. X., and Hertzog, P. J. (1992). Validation of the MTT test dye assay for enumeration of cells in proliferative and antiproliferative assay. Biochem. Int. 27, 501-510.

Marcangelo, M. J., and Ovsiew, F. (2007). Psychiatric aspects of epilepsy. Psychiatr. Clin. North Am. 30, 781-802. doi: 10.1016/j.psc.2007.07.005

Mehla, J., Reeta, K. H., Gupta, P., and Gupta, Y. K. (2010). Protective effect of curcumin against seizures and cognitive impairment in a pentylenetetrazolekindled epileptic rat model. Life Sci. 87, 596-603. doi: 10.1016/j.lfs.2010. 09.006

Meldrum, B. S. (2002). Implications for neuroprotective treatments. Prog. Brain Res. 135, 487-495. doi: 10.1016/S0079-6123(02)35046-5

Miller, L. C., and Tainter, M. (1944). Estimation of the ED50 and its error by means of logarithmic-probit graph paper. Exp. Biol. Med. 57, 261-264. doi: 10.3181/00379727-57-14776

Misra, H. P., and Fridovich, I. (1972). The role of superoxide anion in the auto oxidation of epinephrine and a simple assay of superoxide dismutase. J. Biol. Chem. 247, 3170-3175.

Mittal, O. P., Tammz, C., and Reichstein, T. (1962). Glycosides and aglycons. CCXXVII. The glycosides of Pergularia extensa. Helv. Chim. Acta 45:907. doi: 10.1002/hlca.19620450320

Moongkarndi, P., Kosem, N., Kaslungka, S., Luanratana, O., and Pongpan, N. (2004). Neungton N. Antiproliferation, antioxidation and induction of apoptosis by Garcinia mangostana (mangosteen) on SKBR3 human breast cancer cell line. J. Ethnopharmacol. 90, 161-166. doi: 10.1016/j.jep.2003.09.048

Nachlas, M. M., Margulies, S. I., Goldberg, J. D., and Seligman, A. M. (1960). The determination of lactic dehydrogenase with a tetrazolium salt. Anal. Biochem. 1, 317-326. doi: 10.1016/0003-2697(60)90029-4

Narkilahti, S., Nissinen, J., and Pitkanen, A. (2003). Administration of caspase 3 inhibitor during and after status epilepticus in rat: effect on neuronal damage and epileptogenesis. Neuropharmacology 44, 1068-1088. doi: 10.1016/S00283908(03)00115-1

Niessen, H. G., Angenstein, F., Vielhaber, S., Frisch, C., Kudin, A., Elger, C. E., et al. (2005). Volumetric magnetic resonance imaging of functionally relevant structural alterations in chronic epilepsy after pilocarpine induced status epilepticus in rats. Epilepsia 46, 1021-1026. doi: 10.1111/j.1528-1167.2005. 60704.x

Noor, N. A., Mohammed, H. S., Khadrawy, Y. A., Ezz, H. S. A., and Radwan, N. M. (2015). Evaluation of the neuroprotective effect of taurine and green tea extract against oxidative stress induced by pilocarpine during status epilepticus. J. Basic Appl. Zool. 72, 8-15. doi: 10.1016/j.jobaz.2015.02.001

Pahuja, M., Jogender, M., Reeta, K. H., Manjari, T., and Gupta, Y. K. (2013). Effect of Anacyclus pyrethrum on pentylenetetrazole-induced kindling, spatial memory, oxidative stress and Rho-kinase II expression in mice. Neurochem. Res. 38, 547-556. doi: 10.1007/s11064-012-0947-2

Patsoukis, N., Zervoudakis, G., Georgiou, C. D., Angelatou, F., Matsokis, N. A., and Panagopoulos, N. T. (2005). Thiol redox state and lipid and protein oxidation in the mouse striatum after pentylenetetrazol-induced epileptic seizure. Epilepsia 46, 1205-1211. doi: 10.1111/j.1528-1167.2005.63704.x

Pitkanen, A. (2010). Therapeutic approaches to epileptogenesis-hope on the horizon. Epilepsia 51, 2-17. doi: 10.1111/j.1528-1167.2010.02602.x

Pitkanen, A., Kharatishvili, I., Narkilahti, S., Lukasiuk, K., and Nissinen, J. (2005). Administration of diazepam during status epilepticus reduces development and severity of epilepsy in rat. Epilepsy Res. 63, 27-42. doi: 10.1016/j.eplepsyres. 2004.10.003

Rahmati, B., Mohsen, K., Mehrdad, R., and Parisa, A. (2013). Anti-epileptogenic and antioxidant effect of Lavandula officinalis aerial part extract against pentylenetetrazol-induced kindling in male mice. J. Ethnopharmacol. 148, 152-157. doi: 10.1016/j.jep.2013.04.004

Schulz, J. B., Lindenau, J., Seyfried, J., and Dichgans, J. (2000). Glutathione, oxidative stress and neurodegeneration. Eur. J. Biochem. 267, 4904-4911. doi: 10.1046/j.1432-1327.2000.01595.x

Shin, E. J., Jeong, J. H., Chung, Y. H., Kim, W. K., Ko, K. H., Bach, J. H., et al. (2011). Role of oxidative stress in epileptic seizures. Neurochem. Int. 59, 122-137. doi: 10.1016/j.neuint.2011.03.025

Sinha, A. K. (1972). Colorimetric assay of catalase. Anal. Biochem. 47, 389-394. doi: 10.1016/0003-2697(72)90132-7

Sravani, K. M. R., Kumar, C. K. A., Lakshmi, S. M., and Rani, G. S. (2012). Psychopharmacological profiles of Pergularia daemia (forsk.) chiov. Asian J. Pharm. Clin. Res. 5, 112-114.

Sridevi, G., Prema, S., Sekar, S., and Sembulingam, K. (2014). Phytochemical analysis of Pergularia daemia for its bioactive components through gas chromatographic mass spectrometry (GCMS). IOSR J. Phar. 4, 41-46. doi: 10.9790/3013-0405041046

Stafstrom, C. E. (2006). "Behavioral and cognitive testing procedures in animal models of epilepsy," in Models of Seizures and Epilepsy, eds A. Pitkanen, P. A. Schwartzkroin, and S. L. Moshé (Amsterdam: Elsevier).

Suresh, K. V., and Mishra, S. H. (2008). Hepatoprotective effect of Pergularia daemia (Forsk.) ethanol extract and its fraction. Indian J. Exp. Biol. 46, $447-452$.

Syed, A. R. N., Abdul, W. N., and Abd, M. S. N. (2013). In vitro morphological assessment of apoptosis induced by antiproliferative constituents from the rhizomes of Curcuma zedoaria. Evid. Based Complement. Alternat. Med. 2013:257108. doi: 10.1155/2013/257108

Taiwe, G. S., Moto, F. C., Ayissi, E. R., Ngoupaye, G. T., Njapdounke, J. S., Nkantchoua, G. C. N., et al. (2015). Effects of a lyophilized aqueous extract of Feretia apodanthera Del. (Rubiaceae) on pentylenetetrazole-induced kindling, oxidative stress, and cognitive impairment in mice. Epilepsy Behav. 43, 100-108. doi: 10.1016/j.yebeh.2014.11.022

Todorova, V. K., Harms, S. A., Kaufmann, Y., Luo, S., Luo, K. Q., Babb, K., et al. (2004). Effect of dietary glutamine on tumor glutathione levels and apoptosis-related proteins in DMBA induced breast cancer of rats. Breast Cancer Res.Treat. 88, 247-256. doi: 10.1007/s10549-004-0783-4

Turski, W. A., Cavalheiro, E. A., Schwarz, M., Czuczwar, S. L. J., Kleinrok, Z., and Turski, L. (1983). Limbic seizures produced by pilocarpine in rats: behavioural, electroencephalographic and neuropathological study. Behav. Brain Res. 9, 315-335. doi: 10.1016/0166-4328(83)90136-5

Veerendra, K. M. H., and Gupta, Y. K. (2002). Effect of different extracts of Centella asiatica on cognition and markers of oxidative stress in rats. J. Ethnopharmacol. 79, 253-260. doi: 10.1016/S0378-8741(01)00394-4

Wahi, A. K., Ravi, J., Hemalatha, S., and Singh, P. N. (2002). Anti-diabetic activity of Daemia extensa R. Br. J. Nat. Rem. 2, 80-83. doi: 10.18311/jnr/ $2002 / 350$ 
Waldbaum, S., and Patel, M. (2010). Mitochondria, oxidative stress, and temporal lobe epilepsy. Epilepsy Res. 88, 23-45. doi: 10.1016/j.eplepsyres.2009.09.020

Wilbur, K. M., Bernhein, F., and Shapiro, O. W. (1949). The thiobarbituric acid reagent as a test for the oxidation of unsaturated fatty acids by various agents. Arch. Biochem. Biophys. 24, 305-313.

Xavier, S. M., Barbosa, C. O., Barros, D. O., Silva, R. F., Oliveira, A. A., and Freitas, R. M. (2007). Vitamin C antioxidant effects in hippocampus of adult Wistar rats after seizures and status epilepticus induced by pilocarpine. Neurosci. Lett. 420, 76-79. doi: 10.1016/j.neulet.2007.04.056

Yamamoto, H. A., and Mohanan, P. V. (2003). Ganglioside GT1B and melatonin inhibit brain mitochondrial DNA damage and seizures induced by kainic acid in mice. Brain Res. 964, 100-106. doi: 10.1016/S0006-8993(02)04083-0
Conflict of Interest Statement: The authors declare that the research was conducted in the absence of any commercial or financial relationships that could be construed as a potential conflict of interest.

Copyright () 2017 Kandeda, Taiwe, Moto, Ngoupaye, Nkantchoua, Njapdounke, Omam, Pale, Kouemou and Ngo Bum. This is an open-access article distributed under the terms of the Creative Commons Attribution License (CC BY). The use, distribution or reproduction in other forums is permitted, provided the original author(s) or licensor are credited and that the original publication in this journal is cited, in accordance with accepted academic practice. No use, distribution or reproduction is permitted which does not comply with these terms. 